\title{
ARTYKUŁY
}

Agnieszka Franczyk-Cegła

Zakład Narodowy im. Ossolińskich, Wrocław

agnieszka.franczyk-cegla@ossolineum.pl

(iD) 0000-0002-1231-925X

\section{Księgozbiór karmelitów dawnej obserwancji w Sąsiadowicach}

\section{The Ancient Observance Carmelites book collection in Sąsiadowice}

\begin{abstract}
The monastery of the Ancient Observance Carmelites in Sąsiadowice, former Przemyśl diocese, had one of the largest Carmelite libraries within the Polish territory in the 19th century. The article aims at the reconstruction of the Sąsiadowice book collection, and description of the library functioning, basing on the preserved archival materials and copies of the books dispersed in the years 1917 and 1946, currently stored in three institutions: the National Ossoliński Institute, the Stefanyk National Science Library in Lviv, and the Carmelites Archive and Library in Cracow.
\end{abstract}

Keywords: monastic inventories, Ancient Observance Carmelites, Sąsiadowice, monastery library.

Słowa klucze: inwentarze klasztorne, karmelici dawnej obserwancji, Sąsiadowice, księgozbiory klasztorne.

„Z Badań nad Książką i Księgozbiorami Historycznymi” - Udział zagranicznych recenzentów w ocenie publikacji; Stworzenie anglojęzycznej wersji wydawniczej publikacji; Digitalizacja tomów archiwalnych rocznika w celu zapewnienia otwartego dostępu do nich przez Internet oraz wdrożenie i utrzymanie cyfrowej platformy redakcyjnej - zadanie finansowane w ramach umowy nr 653/P-DUN/2019 ze środków Ministra Nauki i Szkolnictwa Wyższego przeznaczonych na działalność upowszechniającą naukę. 
W 1603 r. w Sąsiadowicach, dużej wsi leżącej wówczas w ziemi przemyskiej (obecnie na płn.-zach. Ukrainy), pojawili się karmelici dawnej obserwancji. Sprowadził ich Jan Szczęsny Herburt, który w imieniu swojego siedmioletniego synowca, Wojciecha Erazma Herburta, wystąpił do bpa Macieja Pstrońskiego z prośbą o możliwość założenia w Sąsiadowicach pierwszego na Rusi Czerwonej klasztoru karmelitów. Pomimo trudnych początków zakonnicy stworzyli za wsią na wzgórzu zwanym Górą Łaskawą (łac. Mons Placidus) ośrodek życia religijnego z kultem św. Anny, który przetrwał najazdy tatarskie w XVII w., kasaty klasztorne w XVIII-XIX w. oraz wojny światowe i przymusowe wysiedlenie w wieku XX zakończone w 2011 r. powrotem braci do Sąsiadowic ${ }^{1}$.

Klasztor sąsiadowicki posiadał jedną z zasobniejszych bibliotek karmelitańskich na ziemiach polskich ${ }^{2}$. Brak wczesnych archiwaliów ${ }^{3}$ utrudnia rekonstrukcję jej zasobów oraz historii podczas pierwszych 150 lat jej istnienia. Najstarsze źródło archiwalne (inwentarz biblioteczny) datowane jest na lata 1766-1780; kolejne trzy zachowane inwentarze pochodzą z XIX w. (1822, $1840,1871)^{4}$. Wszystkie one zostały wykonane przy okazji sporządzania inwentarzy dóbr klasztornych.

1 Więcej na temat historii klasztoru zob. A. Franczyk-Cegła, Zarys dziejów klasztoru oo. karmelitów oo. Sąiadowicach, „Nasza Przeszłość” 2015, nr 125 , s. 75-126.

2 Zob. F. Radziszewski, Wiadomość historyczno-statystyczna: o znakomitszych bibliotekach $i$ archiwach, publicznych i prywatnych tak niegdyś ... w Królestwie Polskiem, Galicyi, W. Ks. Poznańskiem i Zachodnich guberniach Państwa Rossyjskiego, Kraków 1875, s. 74. Autor odnotowuje bibliotekę sąsiadowicką jako jedną z dziewięciu znaczących bibliotek karmelitów dawnej obserwancji (na ówczesne 64 klasztory).

3 Wyjątkiem jest wzmianka w dokumentacji kapituły prowincji: w 1626 r. napomniany został Chryzostom Ługowski (zm. 1644), były przeor klasztoru karmelitów w Oborach w 1616-1618 (zob. Archiwum OO. Karmelitów na Piasku w Krakowie, dalej: AKKr, sygn. 93, k. 28r.), który na żądanie zakonników miał zwrócić polską Biblię daną klasztorowi św. Anny przez niejakiego Młodeckiego (tamże, k. 55r.).

4 Zachowane archiwalia (przechowywane obecnie w większości w AKKr; pojedyncze dokumenty znajdują się także w Archiwum Archidiecezjalnym w Przemyślu (dalej: AAPrz.), Centralnym Państwowym Archiwum Historycznym Ukrainy we Lwowie (dalej: CPAHL), Zakładzie Narodowym im. Ossolińskich we Wrocławiu (dalej: ZNiO) oraz Archiwum Głównym Akt Dawnych w Warszawie) datowane są na XVIII-XX w. Najstarszym zachowanym dokumentem jest kopiarz przywilejów i nadań dla klasztoru sporządzony w 1746 r. (AKKr, sygn. 567) . Wcześniejsze akty z 1. 1591-1685, które były wymieniane jeszcze w inwentarzu z 1871 r. (CPAHL, fond 146, sprawa 20a, opis 5 (dalej: 146/20a/5), s. 61-62), prawdopodobnie uległy zniszczeniu na przełomie 1914/1915 r., gdy klasztor zajmowały wojska rosyjskie (Lwowska Narodowa Naukowa Biblioteka Ukrainy im. W. Stefanyka, dalej: LNNBU, rps 5/5237/III, s. 6). Brak również XV-XVI-wiecznych akt parafialnych przechowywanych w kościele św. Mikołaja, zniszczonych podczas częstych najazdów tatarskich, m. in. w 1560, 1615 i 1624 r. Zob. AAPrz, rps 1653, s. 301; AKKr, sygn. 567, s. 55; Schematismus universi venerabilis cleri saecularis et regularis dioecesis rit. lat. Premisliensis pro Anno Domini 1866, Jasło 1865 , s. 56 . 
Pierwszy zachowany spis biblioteczny zatytułowany Bibliotheca Conventus $S$. Annae ${ }^{5}$ jest częścią inwentarza kościoła i klasztoru z ok. 1766-1780 r. ${ }^{6}$ Poprzedza go rozdział zatytułowany Papiery figuralne, w którym odnotowano przechowywane w klasztorze rękopisy muzyczne - msze, litanie, nieszpory, komplety, psalmy, arie, antyfony, motety, tria, symfonie ${ }^{7}$. Katalog ksiąg w bibliotece sporządzono alfabetycznie podając skrócony tytuł, rodzaj sygnatury, którym był numer książki na półce (sub numero ...) oraz format. Z inwentarza wynika, że książki ułożone były tematycznie, a ich liczba sięgała 390.

Drugi spis książek z klasztoru sąsiadowickiego sporządzono w $1822 \mathrm{r}^{8}{ }^{8}$, także włączając go do inwentarza dóbr. Katalog, zatytułowany Cathalogus librorum in Bibliotheca Conventus Sasiadovicensis P.P. Carmelitarum de Monte placido sub titulo Sanctae Annae reperitorum. Mense Maio 1822 Anno conscriptorum, podzielony jest tematycznie na dziewięć działów: libri concionatorum, libri homiliarum, libri theologorum, libri iuridici, libri historici, libri philosophorum, poetorum et grammaticorum, libri meditationum et de vita sanctiis, libri praecum diurnalium et manualium, libri miscellanei. Sporządzono go w starannej tabeli, podając liczbę porządkową, tytuł dzieła, liczbę woluminów, autora, miejsce i datę wydania oraz informacje o egzemplarzu (defekty, najczęściej opisane ogólnie typu sine principio et fine). Po każdym dziale pozostawiano także wolne miejsce na dopisanie nowych nabytków. Biblioteka liczyła wówczas 581 dzieł w 785 woluminach. Najliczniejszą grupę stanowily książki z dziedziny teologii, tj. komentarze, konkordancje, pisma Ojców Kościoła i teologów nowożytnych w obronie Kościoła - ich liczba sięgnęła 167 dzieł. Na kolejnych miejscach sytuują się zbiory kazań (102 dz.), homilii (96 dz.), książki z dziedziny filozofii, poetyki i gramatyki (79 dz.), historii (38 dz.), medytacji chrześcijańskiej i hagiograficzne (34 dz.), prawnicze ( $25 \mathrm{dz}$.), modlitewniki (23 dz.) oraz miscellanea (17 dz.), wśród których odnotowano pozycje takie jak Iournal ou description du merveilleux voyage de Guilliaume Schouten (Amsterdam 1618), La Saxe Galante Karla Ludwiga von Pöllnitz (wyd. nieustalone) czy Politicorum sive civilis doctrinae libri sex Justusa Lipsiusa (Lich 1604). Do spisu książek z 1822 r. dopisywano kolejne nabytki biblioteczne. Do roku 1829 (kiedy to przeprowadzono wizytację i zamknięto katalog ${ }^{9}$ ) stan księgozbioru powiększył się o 26 pozycji w 29 woluminach, w większości wpisanych do rubryki Libri Miscelanei.

5 Obecnie przechowywany w AAKr. pod sygn. 568, s. 47-56.

6 Inwentarz nie jest datowany, ale wymieniony jest w nim Aleksander Borzęcki jako sprawujący urząd podstolego koronnego, co miało miejsce właśnie w 1. 1766-1780.

AKKr, sygn. 568, s. 44-46.

8 Obecnie przechowywany w AAPrz. pod sygn. 1653, s. 29-51.

9 W wizytacji z 1828 r. zanotowano skrótowo, że klasztor posiada książki kościelne: dziesięć mszałów oprawnych wielkich, trzy mszały rekwialne, jeden mszał rzymski, jeden mszał ruski, dwie agendy, jedna z 1824 r. (AAPrz., rps 1653, k. 178v.). Wizytacja przeprowadzona rok później odnotowała brak następujących ksiąg kościelnych w porównaniu do 1828 r.: trzech teczek rekwialnych, mszału ruskiego, dwóch agend. 
Trzeci spis książek zachował się w inwentarzu klasztornym spisanym w języku niemieckim w grudniu $1840 \mathrm{r}^{10}$ Zawiera on księgi przechowywane w zakrystii kościoła św. Anny (12 mszałów, kancjonał, agendę, księgi metrykalne - narodzin z 1. 1716-1837, ślubów i zgonów z l. 1741-1837) oraz książki przechowywane w bibliotece klasztornej. W katalogu bibliotecznym zapisano 427 dzieł, a więc o 180 mniej niż w 1829 r.! Różnica ta była rezultatem nie tyle bliżej nieokreślonych strat, ile niedokładnością spisującego inwentarz, który z nie wiadomych powodów nie odnotował niektórych ksiąg, np. filozoficznych, które pojawiają się zarówno w inwentarzu z 1822 r., jak i z $1871 \mathrm{r}$.

Ostatni znany spis biblioteczny zachował się w inwentarzu z $1871 \mathrm{r} .{ }^{11}$ Podobnie jak spis z 1840 r. katalog podzielony został na książki „ściśle kościelne" 12 , przechowywane w zakrystii kościoła św. Anny, książki i rękopisy literackie oraz rękopisy dotyczące klasztoru przechowywane w bibliotece klasztornej. Opis ksiąg kościelnych zawiera tytuł, miejsce i datę wydania, liczbę woluminów, stan egzemplarza (dobry/średni/zły), wartość książki w złotówkach lub koronach. Są wśród nich: dziesięć mszałów, Rytuał Rzymski, Ewangeliarz, kancjonał, 12 ksiąg parafialnych (narodzin z 1. 1716-1870 oraz małżeństw i zgonów z 1. 1741-1870 dla Sąsiadowic; urodzeń dla Czapli, Humieńca, Janowa i Woli z 1. 1844-1870 ${ }^{13}$ ). Inwentarz biblioteki klasztornej nie zawiera notatki

10 CPAHL, rps 146/ 20a/ 51, k. 6r-11v.

11 Tamże, s. 35-60. Zob. też U. Paszkiewicz, Inwentarze i katalogi bibliotek z ziem wschodnich Rzeczypospolitej do 1939 r. Suplement 1, Warszawa 2000, s. 184, poz. 717-719.

12 Tamże, s. 35-36.

13 Losy owych ksiąg pozostają nieznane (w AAKr. przechowywane są późniejsze księgi metrykalne z 1. 1874-1946; są to AKKr, sygn. 577: Liber natorum parochiae Sasiadowice ... Tomus VI [1. 1874-1923]; AKKr, sygn. 578: Liber natorum [1. 1944-1946]; AKKr, sygn. 579: Liber bannorum parochiae Sasiadowice... [1. 1910-1946]; AKKr, sygn. 580: Volumen V. Liber copulatorum ecclesiae parochialis simul regularis Sasiadovicensis... [1. 1900-1936]). Wiadomo, że niektóre akta sąsiadowickie w 1927 r. zostały złożone przez przeora jako administratora parafii w archiwum diecezjalnym w Przemyślu na mocy rozporządzenia biskupiego z 1927 r., według którego wszystkie dokumenty przedrozbiorowe (pergaminowe, wizytacje, metryki itp.) miały zostać przesłane do tegoż archiwum. Przeor sąsiadowicki złożył tam metryki od 1716 r. oraz rachunki od XVII w. W czasie II wojny światowej z Przemyśla wywieziono do Lwowa 810 tomów najstarszych ksiąg z metrykalnych sprzed 1772 r., w tym metryki sąsiadowickie. Błędna jest powtarzana informacja jakoby wywieźli je do Lwowa Niemcy, by udowodniać germańskie pochodzenie ludności ziemi przemyskiej; metryki zwieziono wcześniej, za czasów okupacji sowieckiej, w ramach tzw. koncentracji, czyli zabezpieczania i przejmowania przez Sowietów akt z różnych urzędów i instytucji religijnych. Akta metrykalne zostały skoncentrowane we lwowskim Urzędzie Stanu Cywilnego, ZAGS. Gdy Lwów zajęli Niemcy, władze niemieckie zwróciły parafiom wszystkie akta od około 1865 r. Metryki wcześniejsze zostały włączone do Archiwum Państwowego we Lwowie, lecz z powodu braku miejsca w magazynach archiwum, umieszczono je w klasztorze dominikanów we Lwowie wraz z metrykami z Archiwum Archidiecezjalnego we Lwowie. Tam, wraz z innymi aktami metrykalnymi, które wcześniej znajdowały się w Archiwum, utworzono z nich komórkę Metrikenstelle, wchodzącą w skład Sippenstelle (urząd genealogiczny), podległy Bevölkerungswesen und Fürsorge (Wydział ds. ludności i opieki) przy Urzędzie Okręgu Galicja. Placówka, kierowana przez Niemkę o nazwisku Rudloff, zajmowała się przeprowadzaniem kwerend dotyczących po- 
na temat stanu egzemplarza ani ceny. Odnotowano tam 782 pozycje, w tym dziewięć rękopisów oraz pozycje typu „Kazania różne różnych autorów”, bez daty, miejsca wydania i wskazania liczby egzemplarzy. Wśród rękopisów były następujące tytuły: „Tractatus de actibus”, „Historie rozmaite”, „Rzeczy niektóre rozmaite”, „Curiosa varii generis”, „Amerykanie. Tragedya” z 1750 r., „De eloquentia”, „Meditationes”, „Memoranda regni Poloniae”, „Cyrkularze dawnieysze”, „Małpa człowiek"14. Samych książek w bibliotece było zatem ok. 993 woluminów (776 dz.), a łącznie zakonnicy posiadali 805 dzieł (ksiąg kościelnych oraz w bibliotece, a także manuskryptów literackich). Książki w inwentarzu starano się spisać tematycznie. Podobnie jak w inwentarzach z 1822 i 1840 r., także i tu nie wspomniane są szczegółowo muzykalia wymieniane w inwentarzu z ok. 1766-1780 r. ${ }^{15}$ Trzecia część katalogu obejmowała rękopisy archiwalne z 1. 1591-1817 dotyczące funkcjonowania kościoła i klasztoru: erekcje, zapisy na rzecz karmelitów, kopiariusze nadań. W inwentarzu pojawiają się wzmianki o innym katalogu bibliotecznym, z 1856 r., którego nie udało się odnaleźć. Inwentarz z 1871 r. sporządzono przepisując inwentarz z 1856 r. i odnotowując, których książek brakuje w porównaniu do roku 1856. W kilku miejscach inwentaryzujący zrobił pomyłki typowe przy przepisywaniu, np. w poz. 57 zapisał błędnie adres wydawniczy dzieła z poz. 58, a w poz. 58 i 59 zamienił adresy wydawnicze.

$\mathrm{Z}$ powodu braku wczesnych archiwalnych źródeł oryginalnych do historii klasztoru niemożliwe jest oszacowanie liczby książek oraz zrekonstruowanie organizacji i funkcjonowania biblioteki przed II połową XVIII w. Wpisy proweniencyjne pokazują, że księgozbiór zaczął się formować w okresie założenia klasztoru. Książki do biblioteki napływały wówczas pod postacią darów, jako spuścizna po sąsiadowickich zakonnikach lub w wyniku koncentracji z pobliskich kościołów ${ }^{16}$. Pewnym jest, że osobne pomieszczenie na biblio-

chodzenia. W okresie wojennym metrykami zajmował się m.in. dr Michał Wąsowicz, pracownik Archiwum Państwowego. To jemu zawdzięcza się zachowanie części metryk, bowiem archiwiści radzieccy postulowali przekazanie akt sprzed $1840 \mathrm{r}$. na makulaturę. Wąsowiczowi udało się przekonać ich, by tego nie robić. W 1942 r., za czasów okupacji niemieckiej, Wąsowicz opracowywał zasób przygotowując $\mathrm{w}$ dwóch egzemplarzach maszynowy inwentarz (jedna kopia została przekazana do Ossolineum - obecnie zaginiona). W połowie maja 1944 r. metryki diecezji przemyskiej z klasztoru dominikanów zostały wywiezione przez Sippenamt do Rabki, gdzie przebywała też Rudloff. Metryki zaginęły; według krążących wśród miejscowej ludności pogłosek miały zostać spalone przez Sowietów. Zob. J. Kwolek, Archiwa diecezji przemyskiej ob. łac., Przemyśl 1927, s. 27, 52; ZNiO, rps 16600, k. 134; rps 16599, k. 130; M. Wąsowicz, Ze wspomnień archiwisty (1929-1953), „Miscellanea Historico-Archivistica” 1985, t. 26, s. 91-97.

14 CPAHL, rps 146/20a/51, s. 35, 45, 46, 49, 52, 56, 57.

15 Wyjątkiem są kantaty zapisane w inwentarzu ksiąg kościelnych. Zob. Aneks I, Księgi ściśle kościelne, poz. 9.

16 Zob. A. Franczyk-Cegła, Fragmenty ksiegozbioru klasztoru karmelitów w Sasiadowicach w zbiorach Zaktadu Narodowego im. Ossolińskich, „Hereditas Monasteriorum”2015, nr 6, s. 251-290. 
tekę wygospodarowano po wybudowaniu murowanego kościoła w $1742 \mathrm{r}^{17}$, a ok. 1754 r. zaczęto porządkować księgozbiór ${ }^{18}$ wpisując do części egzemplarzy noty proweniencyjne potwierdzające ich przynależność do konwentu sąsiadowickiego oraz naklejając na grzbiecie woluminów papierową nalepkę informującą o autorze, tytule książki i numerze tomu. Część książek zakonnicy musieli kupować, jednak w jedynych zachowanych księgach przychodów i rozchodów, które pochodzą dopiero z XVIII-XIX w. ${ }^{19}$, zakupy biblioteczne stanowią ułamek wszystkich wydatków. I tak zakonnicy wydawali pieniądze na „książki jubileuszowe”, „książki kupione do użytku parafialnego kościoła”"20, „książkę zawierającą modlitwy i pieśni parochialne”21, „oprawy książki dla chorych"22. Warto zauważyć, że wydatki na bibliotekę nie stanowiły osobnej pozycji w inwentarzu - wymienione wyżej książki zapisano jako wydatki na potrzeby kościelne i wydatki nadporządkowe w latach 1826-1828.

Z biblioteki klasztornej korzystali zarówno zakonnicy, jak i goście. I tak np. do inwentarza z 1822 r. dołączono rewers ,na wzięte książki pożyczonym sposobem" z $1821 \mathrm{r}^{23}$ Pożyczającym był ks. Adam Janowski, profesor wykładający dogmatykę w Instytucie Teologicznym w Przemyślu w 1. 1819$1833^{24}$. W inwentarzu z $1871 \mathrm{r}$. stwierdzono natomiast, że w porównaniu z 1856 r. brakuje 39 pozycji; zakonnicy nie potrafili jednak wskazać przyczyn takiego stanu rzeczy. Twierdzili, że prawdopodobnie książki te wypożyczono na zewnątrz; nie można jednak stwierdzić tego z pewnością, ponieważ nie prowadzono księgi wypożyczeń ${ }^{25}$. Niektóre z tych książek zwrócono w późniejszym czasie. Zarówno na rewersie z 1821 r., jak i w inwentarzu z 1871 r., wśród wypożyczonych druków przeważały kazania oraz dzieła dotyczące historii.

17 CPAHL 146/20a/51, s. II.

18 We wpisie proweniencyjnym w egz. druku z biblioteki sąsiadowickiej, obecnie w zbiorze Działu Starych Druków pod sygn. XVI.Qu.11583, zanotowano rok 1754, gdy do książki podarowanej w 1610 r. wpisywano jej przynależność do zbioru w Sąsiadowicach: Liber, cui titulus Sermones Spirituales applicatus huic S. Annae Montis placidi Juventui olim a patre Laurentio Gardecki ... Sacerdote Ord. Carmelitt. Decano S. Nicolai ao Dni 1598 2da Julii subscriptus vero anno ab hoc anno 144 id est 1754.

19 Księgi gospodarcze z XVII oddano w 1927 r. do archiwum archidiecezji przemyskiej, skąd wywiezione przez Niemców do Lwowa, a następnie do Rabki, zaginęły. Zob. przyp. 16.

20 AAPrz 1653, k. 120v. (rok 1826).

21 Tamże, k. 154v. (rok 1827).

22 Tamże, k. 283 r. (rok 1828).

23 AAPrz 1653, s. 43.

24 Dzieje teologii katolickiej w Polsce. T. 3, Wiek XIX i XX. Cz. 1, red. M. Rechowicz, Lublin 1976, s. 147; zob. też np. Schematismus des Königreiches Galizien und Lodomerien Für das Jahr 1827, Lemberg [1826], s. 745.

25 CPAHL, rps 146/20a/51: 60. 
Tragiczny wpływ na bibliotekę sąsiadowicką miała I wojna światowa. Na przełomie października i listopada 1914 r. przez Sąsiadowice przetoczył się front, karmelici zostali wysiedleni, część mienia klasztornego, w tym bibliotekę, zniszczono, a w samym klasztorze zakwaterowano szpital polowy wojsk rosyjskich. Gdy Eugeniusz Szmurło, wysłannik petersburskiej Akademii Nauk zabezpieczający zbiory po przejściu frontu dotarł do Sąsiadowic na początku 1915 r., zastał, jak później pisał w raporcie, tylko ostatki biblioteki zakonnej. Meble biblioteczne wyniesiono na opał, sterta druków, papierów i rękopisów na podłodze sięgała pół metra, a same książki były częściowo podarte, częściowo zaś poginęły. Szmurło wymienił w raporcie, co znalazł i zebrał:

Wśród zabranych przeze mnie ksiąg jest: „O soczinieniu izdania” z XVI wieku, a inna -

„Mariale eximil viri Bernardini de Busti ordini seraphici Francisco: de singulis festivitatibus beate virginis per modm sermonum tractans" - jeszcze wcześniejsza: 1496 rok $^{26}$.

Nie sporządzono żadnej listy strat, lecz porównując katalogi w XIX-wiecznych inwentarzach z zachowanymi współcześnie zasobami można założyć, że to wówczas zniszczono oryginalne akty z 1. 1591-1685, w tym akt konsekracji nowo wybudowanego kościoła św. Anny z 1591 r., pozwolenie biskupa Macieja Pstrokońskiego na fundację klasztoru z 1603 r. przez Herburtów oraz szereg innych dokumentów do wczesnej historii klasztoru. Biblioteka nie była jednak w tak złym stanie, jak pisał Szmurło. Większość książek udało się uratować. Historyk zebrał ocalałe książki i kazał przenieść do zakrystii, a najcenniejsze druki i rękopisy w czterech skrzyniach przewiózł do Lwowa. Początkowo miał zamiar umieścić je u karmelitów lwowskich, lecz z powodu złego stanu zachowania książek (znaczne uszkodzenia przez owady) zdecydował się oddać inkunabuły oraz cenne druki z XVI w. do Zakładu Narodowego im. Ossolińskich, gdzie - jak sądził - będą miały lepszą opiekę. Po pertraktacjach z Prowincją Zakonu trzy skrzynie książek trafiły do klasztoru karmelitów we Lwowie, a jedna skrzynia do biblioteki Ossolineum, która w zamian przekazała karmelitom szereg dubletów i najnowszych publikacji polskich i zagranicznych ${ }^{27}$.

W skrzyni przekazanej Ossolineum znalazło się 80 tytułów ${ }^{28}$. Szmurło wywożąc z Sąsiadowic cztery skrzynie druków i rękopisów uszczuplił zatem bibliotekę o ok. 250 książek. Oznacza to, że na miejscu teoretycznie pozostało prawie 600 dzieł w około 800 woluminach. Biblioteka przetrwała w stanie

26 CPAHL, rps 5/5237/III, s. 6. Tłum. Helena Dziedzińska. Zob. A. Franczyk-Cegła, Fragmenty księgozbioru klasztoru ..., dz. cyt., s. 120.

27 Zob. tamże, s. 121-123.

28 Tyle druków odnaleziono w Zakładzie Narodowym im. Ossolińskich i Lwowskiej Narodowej Naukowej bibliotece Ukrainy im. W. Stefanyka. Zob. A. Franczyk-Cegła, Knyhozbirnia oo.karmelitiw z Susidowycziw u zibranniach Lwiwśkoji Nacionalnoji Naukowoji Biblioteky Ukrajiny im.W. Stefanyka i Nacionalnoho Zakładu im. Ossolinśkych u Wrocławi, „Zapysky Lwiwśkoji Nacionalnoj i naukowoji biblioteky Ukrajiny imeni W. Stefanyka" 2017, t. 9 (25), [dalej : Knyhozbirnya] s. 24-57. 
nienaruszonym II wojnę światową, choć sam klasztor przechodził różne koleje - w październiku 1940 r. zostali tam zakwaterowani żołnierze rosyjscy, którzy zajęli m.in. całe piętro, gdzie znajdowało się pomieszczenie biblioteczne. W ten sposób zakonnicy stracili dostęp do książek; niedługo potem zostali całkowicie wykwaterowani. Karmelici powrócili do klasztoru w połowie 1941 r. po pojawieniu się w czerwcu wojsk niemieckich ${ }^{29}$. Przebywali tam do lipca 1946 r., gdy na mocy umowy pomiędzy Polskim Komitetem Wyzwolenia Narodowego a Rządem Ukraińskiej Socjalistycznej Republiki Rad dotyczącym ewakuacji obywateli polskich z terytorium U.S.R.R. i ludności ukraińskiej z terytorium Polski, zawartej 9 IX 1944 r., zostali zmuszeni do opuszczenia swojej siedziby i wyjazdu do Polski. Umowa przewidywała, że mienie kościelne również podlega ewakuacji. W praktyce jednak nie respektowano tego zarządzenia, uważając, że kościół jako instytucja jest własnością państwa. Tak też rzecz wyglądała w Samborze, gdzie w biurze repatriacyjnym dla m. in. Sąsiadowic, ukraiński pełnomocnik ds. ewakuacji, niejaki Piatow, uniemożliwiał oficjalny wywóz dóbr kościelnych ${ }^{30}$. Zakonnicy sąsiadowiccy, którzy wyjeżdżali do Polski transportem 9 VII 1946 r. ${ }^{31}$ wraz z 60 rodzinami z Sąsiadowic na Ziemie Odzyskane, przekazali do przewiezienia parafianom naczynia, szaty liturgiczne i XVI-wieczną rzeźbę św. Anny Samotrzeciej. Na stacji granicznej przepuszczono bez rewizji wagony z ludnością cywilną, natomiast wagony z księżmi odczepiono i przeprowadzono dokładną rewizję, szukając, jak wynikało ze słów celników ukraińskich, złotych naczynn ${ }^{32}$. Dzięki zapobiegliwości karmelitów udało się uratować wyposażenie klasztoru sąsiadowickiego; zwrócone przez parafian dobra trafiły do klasztoru w Pilźnie, a następnie do klasztoru karmelitów na Piasku w Krakowie. Niejasne jest, czy zakonnicy zabrali wówczas ze sobą książki z biblioteki klasztornej. Wiadomo, że książki z Sąsiadowic znajdują się obecnie w Ossolineum oraz w klasztorze krakowskim. Do tego ostatniego trafiły zapewne wraz ze zbiorami karmelitów lwowskich, lecz być może pojedyncze egzemplarze zostały także przywiezione w 1946 r. przez zakonników wyjeżdżających z Sąsiadowic. Z pewnośćią nieokreślona część biblioteki została na miejscu w Sąsiadowicach, gdzie umieszczono je w wieży przyklasztornej. Druki te uległy rozproszeniu w latach późniejszych - według

29 P.S. Żuk, Sąiadowice 1939-1945 [mps], Wrocław 1990, s. 17-18.

30 J. Buca, [Repatriacje - ewakuacja. Tekst na podst. dokumentów zespołu nr 527/0 AAN (Rejonowego Pełnomocnika Rządu RP do Spraw Ewakuacji Ludności Polskiej z Ukraińskiej SRR w Samborze,1944-1946)], [online], http://ubocze66.republika.pl/repatriacje/ewakuacja.html, [dostęp 30.01.2016].

31 P.S. Żuk, Sasiadowice 1939-1945, s. 38. Inne podawane daty wyjazdu to czerwiec 1946. Zob. J. Smereka, Ojcowizna, Wrocław 1996 [mps], s.: 58: „16 czerwca wyjechał on [tj. opisywany wcześniej mieszkaniec Sąsiadowic - A.F.-C.] z Sambora [...]. W lipcu transport ten przybył do Wrocławia [...]. Przyjechali między innymi księża i nauczyciele z Sąsiadowic [...]”.

32 P.S. Żuk, tamże. 
mieszkańców zabrał je jeden z sąsiadowiczan i najprawdopodobniej sprzedał. Książki sąsiadowickie z lwowskiego Ossolineum zostały przewiezione do Wrocławia w 1946 r. w ramach daru narodu ukraińskiego dla narodu polskiego wraz z przekazaną częścią ossolińskej kolekcji. Kilka druków z księgozbioru sąsiadowickiego znajduje się też obecnie w zbiorach Lwowskiej Narodowej Naukowej Biblioteki im. Wasyla Stefanyka, która przejęła pozostałą we Lwowie resztę kolekcji ossolińskej. Druki sąsiadowickie, które znajdują się obecnie we Lwowie mogą być pozostałością po tych przejętych przez Szmurłę w 1917 r., lub trafiły tam po 1946 r., po likwidacji klasztoru. Władze ukraińskie koncentrowały bowiem w państwowych instytucjach zbiory przejmowane po 1945 r. po prywatnych instytucjach religijnych; z pewnością przejęły np. znany portret Jana Herburta ( -1577) z XVI w. (wymieniony w inwentarzu z 1871 r.), który kiedyś znajdował się w klasztorze w Sąsiadowicach, a obecnie przechowywany jest w Muzeum Narodowym we Lwowie.

Trzon księgozbioru stanowiły dzieła teologiczne z zakresu teologii moralnej, teologii dogmatycznej, duchowości karmelitańskiej, historii religii, prawa kościelnego, kaznodziejstwa, liturgiki, mistyki, kabały chrześcijańskiej, biblistyki czy patrystyki. Szczególnie liczne były różnego rodzaju kazania w języku łacińskim i polskim. Druki niereligijne stanowiły niecałe 14\% księgozbioru. Były to słowniki, podręczniki do nauki języka, dzieła z zakresu medycyny, historii i polityki, prawa, gospodarstwa, kuchni, encyklopedie, literatura piekna, druki okolicznościowe, dzieła filozoficzne, retoryczne, dzieła z dziedziny matematyki, alchemii i chemii, fizyki, geografii i astronomii. Tytuły te występują raczej pojedynczo niż w większych grupach, toteż trudno w ich przypadku mówić o świadomym i regularnym gromadzeniu. Najwięcej świeckich książek pochodziło z XVIII oraz XIX w.; dotyczyły one historii (23 dz., głównie Polski), prawa ( 9 dz., w tym np. edykty dotyczące Galicji) oraz nauki języków (łaciny, francuskiego, włoskiego - $15 \mathrm{dz}$.), filozofii (19 dz.). Warto zauważyć, że stosunkowo niewiele wśród druków niereligijnych było książek praktycznych, dotyczących np. gospodarstwa, medycyny czy nauk ścisłych, które często dominowały w podręcznych księgozbiorach ziemiańskich z tego samego okresu. W księgozbiorze zakonników znajdował się takie pozycje jak Monitor z 1766 r., Dworzanin Polski Górnickiego z 1566 r. czy dzieło Diabet w swojej postaci Jana Bohomolca z 1773 r. W XIX w. zakonnicy zaczęli wykazywać większe zainteresowanie literaturą piękną - $\mathrm{z}$ tego okresu pochodzi np. komplet dzieł Schillera w języku niemieckim z 1824 r. czy Biblioteka kieszonkowa klasyków polskich pod redakcją Jana Bobrowicza z 1859 r.

Język ksiąg w bibliotece pokazuje, jak wyglądała sytuacja językowa w Kościele polskim w XVI-XIX w. oraz na obszarze diecezji przemyskiej. Większość stanowią dzieła łacińskojęzyczne. Są to prawie wszystkie książki z XVI i dużo druków z XVII w., a więc z okresu, gdy łacina zajmowała dominującą 
pozycję w Kościele i nauce. Drugie pod względem liczebności są druki w języku polskim, głównie z XVIII w. W wieku XIX, gdy oficjalnym językiem Galicji stał się niemiecki, zakonnicy także zgromadzili dużo książek w tym języku.

Analiza miejsca druku książek z księgozbioru sąsiadowickiego pokazuje natomiast zmiany zachodzące w kulturze książki na ziemiach polskich. Druki XVI-wieczne pochodzą w większości z oficyn zagranicznych (najwięcej odpowiednio z Kolonii, Wenecji, Antwerpii, Lyonu); zaledwie cztery wydano w Krakowie. Wynika to z faktu, że choć stolica Polski była ówcześnie prężnym ośrodkiem drukarskim, oficyny nie były w stanie konkurować z bogatą ofertą wydawniczą takich miast jak Kolonia czy Wenecja. Drukarzom krakowskim niejednokrotnie bardziej opłacało się sprowadzać książki z zagranicy i rozprowadzać je na rynku krajowym niż drukować książki, zwłaszcza te kilkusetstronicowe. Sytuacja ta zmieniła się dopiero w wieku XVIII - również w księgozbiorze sąsiadowickim widoczna jest $\mathrm{w}$ tym okresie widoczna przewaga druków wydanych na ziemiach polskich. Wyraźna dominacja takich ośrodków drukarskich jak Lwów czy Wiedeń w tymże księgozbiorze wskazuje natomiast na bliskość tych miast i klasztoru w Sąsiadowicach, przy czym niewykluczone, że książki z Wiednia kupowano przez księgarzy we Lwowie lub Przemyślu utrzymujących ścisłe kontakty z wiedeńskimi dystrybutorami.

Ze współczesnego punktu widzenia do najcenniejszych książek w księgozbiorze sąsiadowickim należały inkunabuły: Sermones de tempore (Strassburg $1498^{33}$ ), Vocabularius rerum (Strassburg 149134), Sermones de laudibus sanctorum Roberta Caracciolusa ([Reutlingen, ca 1495 $]^{35}$ ), Confessionale Antoninusa Florentinusa (Strassburg 1496 ${ }^{36}$ ), Mariale Bernardinusa de Bustis (Strassburg $1496^{37}$ ), Magni hujus seculi exempla $1496^{38}$, Vocabularius (Strassburg 149939). Druki z XVI w. stanowiły 17\% księgozbioru; było wśród nich sześć poloników: jeden druk krakowski w języku polskim ${ }^{40}$ oraz pięć druków krakowskich w języku łacińskim ${ }^{41}$. Do najbardziej interesujących z punktu widzenia biblio-
33 W inwentarzu przestawiono cyfry w dacie na 1489. Zob. poz. 645 Aneksu.
Zob. poz. 241 Aneksu.
Zob. poz. 567 Aneksu.
Zob. poz. 110 Aneksu.
Zob. poz. 411 Aneksu.
8 Wydanie niezidentyfikowane.
39 Zob. poz. 606 Aneksu.
40 Wereszczyński, Józef, Kazania albo ćwiczenia chrześcijańskie na XVIII niedziel, Kraków : And. Piotrkowczyk, 1587.

41 [1] Anzelm z Canterbury, Elucidarius Dialogicus, Cracoviae : In Oficina Typographica Hieronymi Scharffenbergi, [15]49 ; [2] Mikołaj z Błonia, Tractatus sacerdotalis de Sacramentis, (Cracouie : in edib[us] [...] Joa[n]nis Haller, 1519 ; [3] Missale pro itinerantibus secundum cursum ecclesie Cathedralis Cracovien[sis], Cracouie : in Officina Calcographica Hieronymi Vietoris, 1545. [4] Biblia Leopolity - wydanie nieokreślone ; [5] Bartsch Fryderyk, Commentationes in adventum, Kraków 1585. 
logicznego należy nieznane dotychczas wydanie krakowskie Commentationes in adventum Fryderyka Bartscha z 1585 r. Druki XVII w. stanowily 15\%, druki XVIII w. $-32 \%$, druki XIX w. $-21 \%$, druki bez daty wydania, defekty bez początku lub/i końca $-13 \%$.

Inwentarze biblioteczne biblioteki w Sąsiadowicach sporządzane były na podstawie tych już istniejących. Wskazuje na to zapis na końcu z inwentarza z roku 1871 o brakujących pozycjach. W tymże inwentarzu można wyróżnić co najmniej dwie osoby spisujące książki: pierwsza dokładnie notowała autora, miejsce i datę wydania; druga - najprawdopodobniej sporządzająca inwentarz w latach 60. na zasadzie dopisywania książek do poprzedniego - stosowała już zapis skrótowy, bez podawania miejsca wydania (zob. od pozycji $698 \mathrm{w}$ inwentarzu z 1871 r. - Aneks). Pierwszy inwentaryzujący musiał mieć książki w ręku - wskazują na to np. zapisy takie jak poz. 91 (zob. Aneks), gdzie przy dziele Elucidarius dialogicus (Kraków 1549) jako autora podaje Alberta Krotkiewicza. Ów bliżej nieznany Krotkiewicz nie był autorem, lecz byłym właścicielem książki w XVI w., który na ostatniej karcie, nad kolofonem, pozostawił wpis rękopiśmienny: Sum verum Albertus [!] Krotkowicz ${ }^{42}$. Inwentaryzujący szukał również dociekliwie danych bibliograficznych, tak jak przy poz. 269, gdzie w dziele Logica sive Ars cogitandi szukał autora poza kartą tytułową (wyrażony był w imprimatur). Nierzadko popełniał jednak błędy; incydentalnie zdarzają się w inwentarzu nieznane edycje dzieł polskich, lecz z powodu owych błędów należy traktować je ostrożnie.

Podsumowując, karmelici z Sąsiadowic posiadali zasobną bibliotekę, której zawartość znamy dziś dzięki czterem zachowanym inwentarzom z XVIII oraz XIX w. Choć nie prowadzili oni innej dokumentacji bibliotecznej, funkcjonowanie biblioteki można odtworzyć na podstawie inwentarzy oraz zachowanych egzemplarzy książek. Wiadomo, że była ona uporządkowana (książki grupowano tematycznie), gromadzono je drogą kupna, darów bądź przejmowano z okolicznych kościołów. Nieliczne dublety sugerują, że książki wpływały także z prywatnych księgozbiorów zakonników. Katalogi książek sugerują, że biblioteka sąsiadowicka służyła przede wszystkim edukacji zakonników oraz przygotowaniu do pracy duszpasterskiej, która stanowiła ich główną działalność. Potwierdza to tezę, że księgozbiory klasztorne pełniły przede wszystkim funkcję praktyczną ${ }^{43}$. Ponieważ karmelici w Sąsiadowicach nie prowadzili

42 Zakład Narodowy im. Ossolińskich, Dział Starych Druków (dalej: Ossol.), sygn. XVI.O.1026.

43 Np. w inwentarzu karmelitów bosych z Berdyczowa z 1781 r. znajdowało się dużo podręczników, co związane jest z faktem, że klasztor prowadził szkołę. Tego typu wydawnictwa w księgozbiorze sąsiadowickim występują w pojedynczych ilościach. Por. I. Ciborowska-Rymarowicz, Polonika w księgozbiorze klasztornym karmelitów bosych w Berdyczowie (na podstawie katalogu z 1781 r.). Zarys problemu, „Z Badań nad Książką i Księgozbiorami Historycznymi”, tom specjalny, 2017, s. 219-27. 
np. działalności szkolno-wychowawczej czy medycznej, brak tego typu dzieł w ich bibliotece. Obecność literatury świeckiej, zwłaszcza literatury pięknej z XIX w., daje natomiast ciekawy obraz pozareligijnych zainteresowań zakonników. Stan zachowania zbiorów nie był dobry, a okres I wojny światowej znacznie uszczuplił bibliotekę. Jej kres przyniosła likwidacja klasztoru w 1946 ., lecz książki nie zagineły - najcenniejsze zbiory sąsiadowickie znajdują się obecnie w Ossolineum oraz w klasztorze karmelitów krakowskich.

\section{Aneks}

Inwentarz biblioteczny karmelitów w Sąsiadowicach z 1871 r. ${ }^{44}$

I. Księgi ściśle kościelne

\begin{tabular}{|c|c|c|c|c|c|c|c|}
\hline \multicolumn{2}{|c|}{ Liczba porządkowa } & \multirow[t]{2}{*}{ Przedmiot } & \multicolumn{3}{|c|}{ Stan } & \multicolumn{2}{|c|}{$\begin{array}{c}\text { Wartość } \\
\text { w wal. } \\
\text { austr. }\end{array}$} \\
\hline $\begin{array}{c}\text { Bieżą- } \\
\text { ca }\end{array}$ & $\begin{array}{l}\text { dawnego } \\
\text { inwent. }\end{array}$ & & dobry & średni & zly & zlr & $\mathbf{k r}$ \\
\hline \multicolumn{8}{|c|}{$\begin{array}{l}\text { Księgi ściśle kościelne i biblioteka klasztorna } \\
\text { Księgi ściśle kościelne }\end{array}$} \\
\hline 1 & - & $\begin{array}{l}\text { Missale fratrum Ord. Carmel. } \\
\text { Roma } 1856 \text { - oprawny } \\
\text { w czerwony safian z klamrą } \\
\text { i brzegami pozłacanymi }\end{array}$ & & l & & 8 & \\
\hline 2 & - & $\begin{array}{c}\text { Takich samych mszałów } 3 \\
\text { oprawnych w czarną skórę } \\
\text { o } 4 \text { złr }\end{array}$ & & & / & 12 & \\
\hline 3 & - & $\begin{array}{l}\text { Missale Romanum. Editio } \\
\text { jussu Pii V. Mechlinae } 1867 \\
\text { - oprawny w czarną skórę } \\
\text { z złoconymi brzegami. }\end{array}$ & l & & & 4 & \\
\hline 4 & - & $\begin{array}{l}\text { Missale Romanum. Editio jussu } \\
\text { Clementis VIII. Venetiis } 1764 \\
\text { w skórę oprawiony }\end{array}$ & & & l & 2 & \\
\hline
\end{tabular}

44 Sygn. oryg. CPAHL 146/20a/51, s. 35-60. 
Księgozbiór karmelitów dawnej obserwancji w Sąsiadowicach

\begin{tabular}{|c|c|c|c|c|c|c|}
\hline 5 & - & $\begin{array}{c}\text { Missale Ordin. Carm. Romae } \\
1733 \text { oprawiony w skórę }\end{array}$ & & l & 2 & \\
\hline 6 & - & $\begin{array}{l}\text { Missale pro defunctis oprawio- } \\
\text { ny w płótno } 1766\end{array}$ & I & & & 10 \\
\hline 7 & - & $\begin{array}{c}\text { Missale pro defunctis oprawio- } \\
\text { ne w papier }\end{array}$ & & 1 & & 6 \\
\hline 8 & - & Missale rutenicum & & / & & 50 \\
\hline 9 & - & Cantate & & l & & 15 \\
\hline 10 & - & Rituale 1864 & 1 & & & 50 \\
\hline 11 & - & $\begin{array}{l}\text { Evangelia oprawiona w skórę } \\
\text { Leszno } 1855\end{array}$ & I & & I & \\
\hline 12 & - & $\begin{array}{l}\text { Liber natorum ab anno } 1716 \\
\text { ad } 1740\end{array}$ & & & & \\
\hline 13 & - & , , , ", 1740 ad 1784 & & & & \\
\hline 14 & - & 1825 & & & & \\
\hline 15 & - & ", ", ", 1826 " 1844 & & & & \\
\hline 16 & - & 1870 & & & & \\
\hline 17 & - & $\begin{array}{c}\text { " " pro Czaple, Humieniec, } \\
\text { Janów et Wola rajnowaab } \\
\text { anno } 1844 \text { ad } 1870\end{array}$ & & & & \\
\hline 18 & - & $\begin{array}{l}\text { Liber mortuorum ab } 1741 \\
\text { ad } 1784\end{array}$ & & & & \\
\hline 19 & - & ", ", 1785 ", 1840 & & & & \\
\hline 20 & - & , ", " 1841" 1870 & & & & \\
\hline 21 & - & $\begin{array}{l}\text { Liber copulatorum ab } 1741 \\
\text { ad } 1784\end{array}$ & & & & \\
\hline
\end{tabular}




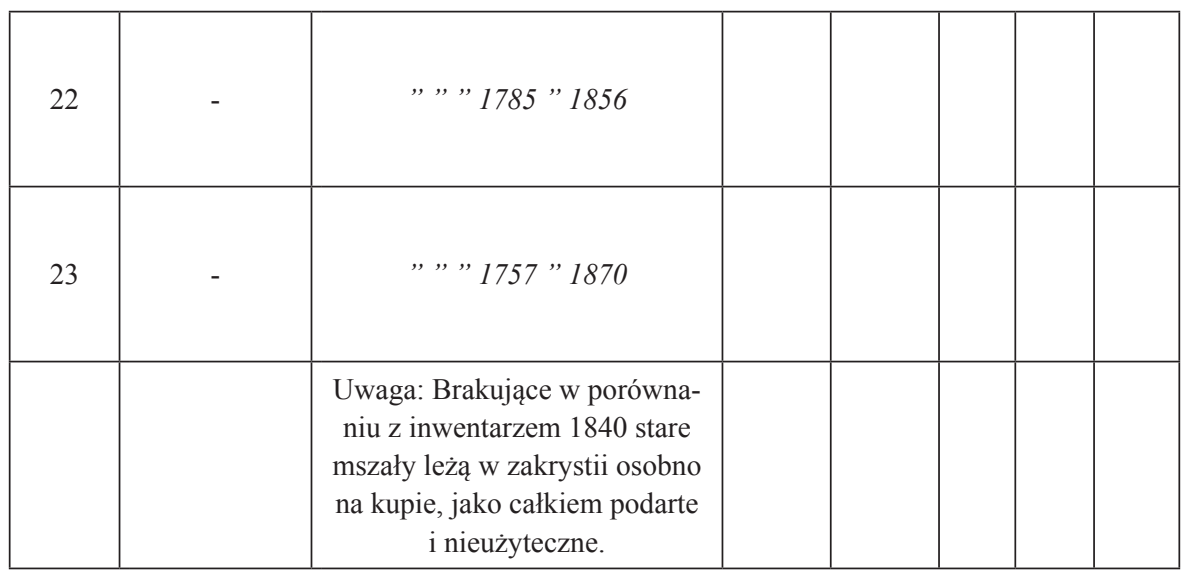

\section{Biblioteka klasztorna ${ }^{45}$}

\begin{tabular}{|c|c|}
\hline Lp. & Przedmiot \\
\hline & Biblioteka klasztorna \\
\hline 1. & Tractatus de Sacramentis - przez Adama Opatoviusa. Kraków $1642^{46}$. \\
\hline 2. & Candelabrum aureum - przez Marcina Alfonsa Vivalda. Brixen 1595. \\
\hline 3. & Tractatus sacerdotalis - przez Mikołaja Plove Kraków $1519^{47}$. \\
\hline 4. & Praelectiones Theologicae. 4 tomy przez Hermana Scholiner 1769. \\
\hline 5. & $\begin{array}{r}\text { Prompta Biblioteka canonica, juridico moralisTheologia } 8 \text { tomów przez Luciusa } \\
\text { Ferraris }- \text { Bononia CIDIDCCLVIII. }\end{array}$ \\
\hline 6. & $\begin{array}{r}\text { Institutiones Theologicae de Deo et de Trinitate w } 2 \text { tom. (1 tom brakuje) przez } \\
\text { karmel. Fr. Thomasza Wenecya 1775. }\end{array}$ \\
\hline
\end{tabular}

45 W edycji inwentarza nie objaśniano pozycji książkowych łatwych do identyfikacji, tj. posiadających tytuł oraz właściwy adres wydawniczy i rok wydania. Korygowano błędnie zapisane dane, literówki, podawano możliwe wydania w przypadku niepełnych opisów książek w inwentarzu oraz odnotowywano, jeśli dana pozycja nie jest cytowana w bibliografiach i/lub literaturze przedmiotu. Zachowano ortografię i interpunkcję oryginału.

46 K. Estreicher, Bibliografia polska. Cz. 3, Stólecie [!] XV-XVIII w układzie abecadtowym (dalej: Estr. XV-XVIII), t. 23, Kraków 1910, s. 368-369.

47 I.e. Nicolaus de Błonie, Tractatus sacerdotalis, Kraków, J. Haller, 1519. Estr. XV-XVIII, t. 2, s. 172. Egzemplarz Biblioteki oo. Karmelitów na Piasku w Krakowie [dalej : BKKr], sygn. XVI.658. Za identyfikację woluminów sąsiadowickich w bibliotece na Piasku Autorka składa serdeczne podziękowania dr. Szymonowi Sułeckiemu. 
Księgozbiór karmelitów dawnej obserwancji w Sąsiadowicach

\begin{tabular}{|c|c|}
\hline 7. & Consilium Tridentinum przez Jana Galamart Trident 1745. \\
\hline 8. & Moralis Christiana pr. ${ }^{48}$ Jakoba Besombes Wenecya 17472 tom. \\
\hline 9. & Explanatio in Psalmos pr. Roberta Belarmina Paryż 1733. \\
\hline 10. & Expositiones Psalmorum David pr. Camila Relsic ${ }^{49}$ Wenecya 1628. \\
\hline 11. & Institutiones Theolog. 2 tomy pr. Antoniego Maria Boranga Wenecya 1766. \\
\hline 12. & De Trinitate p. Grzegorza z Walencyi Ingolstadt $1586^{50}$. \\
\hline 13. & Theologia Dogmatica - 2 tomy. Pr. Xav. Gmeiner. Grecya 1807. \\
\hline 14. & Loci communes - p. Józefa Lang 1613. \\
\hline 15. & Columna et firmamentum veritatis pr. Kiliana Kazenbergera 1738. \\
\hline 16. & Typus omnium scientiarum p. Aegid. Moncurciusza Lugdun. 1591. \\
\hline 17. & Index Librorum prohibitorum Roma 1704. \\
\hline 18. & Corpus juris canonici - Roma 1576. \\
\hline 19. & Casus conscientiae - p. Benedykta XIV Wenecya 1766. \\
\hline 20. & Hortus Pastorum - p. Jakóba Marchantiusza Agripina $1798^{51}$. \\
\hline 21. & Homo apostolicus p. Alfonso di Ligorio Wenecya 1763. \\
\hline 22. & $\begin{array}{l}\text { Nauka dla nowych spowiedników - pr. Pawła Xaw. Brzostowskiego. } \\
\text { Berdyczów } 1774^{52} \text {. }\end{array}$ \\
\hline 23. & Nauka dla spowiedników pr. Kochlera Kraków $1806^{53}$. \\
\hline 24. & Historia apostolica. Paryż 1559. \\
\hline 25. & Decretales Gregorii IX p. Adama Huth 1748. \\
\hline
\end{tabular}

48 Inwentaryzujący stosuje niekiedy skróty $p r$ lub $p$. oznaczające przez.

49 I.e. Pulsicti.

50 Ossol. XVI.Qu.3615-16. Dokładny opis zob. A. Franczyk-Cegła, Knyhozbirnya..., s. 56, poz. 77-78.

51 W oryginale liczba 9 poprawiana. Bibliografie nie notują Hortus Pastorum z 1798 r. Być może chodziło o r. 1708.

52 Estr. XV-XVIII, t. 2, s. 402.

53 K. Estreicher, Bibliografia Polska. 120000 druków. Stolecie XIX (dalej: Estr XIX), t. 2, Kraków 1870, s. 401. 
Agnieszka Franczyk-Cegła

\begin{tabular}{|c|c|}
\hline 26. & Comentaria in psalmos p. Haymona Kolonia $1533^{54}$. \\
\hline 27. & De justitia coelestis p. Hieron. Osori Kolonia 1566. \\
\hline 28. & Explicationes catechetica - p. Zachariasza Ursini. - Heidelberg 1598. \\
\hline 29. & Seelsorger am Kranken- und Sterbebette Köhlera Frankfurt $1810^{55}$. \\
\hline 30. & Thesaurus Sacr Rituum p. Garvantis ${ }^{56}$ Berdyczów $1777^{57}$. \\
\hline 31. & Tractatus de actibus humanis - Manuskrypt. \\
\hline 32. & Examen eclesiasticum p. Felc. Panorm. Kolonia 1744. \\
\hline 33. & Insitutio Parochi - Paulus Segner. Poznań $1746^{58}$. \\
\hline 34. & Panis quotidianus - Gaud. Pikulski. Lwów $1759^{59}$. \\
\hline 35. & Catechismus Romanus - Wenecya 1702. \\
\hline 36. & Katechizm Rzymski - Przemyśl $1763^{60}$. \\
\hline 37. & Erklarung der Katechismus - 6 tomów. Mainz 1829. \\
\hline 38. & Katechizm dla dzieci wiejskich. Korczyński - Lwów $1822^{61}$. \\
\hline 39. & Teologia pasterska - Wilno $1824^{62}$. \\
\hline 40. & Teologia pastoralna - Józef Lauber - Przemyśl $1786^{63}$. \\
\hline 41. & Zasady wymowy frc. - Wilno $1824^{64}$. \\
\hline 42. & Usus et doctrina fratrum - Daniel Tobenz Wiedeń 1783. \\
\hline 43. & Theologia moralis - 4 tomy - Franc. Genet. Basani 1775. \\
\hline
\end{tabular}

54 Ossol. XVI.O.8685. Zob. Knyhozbirnya, s. 44, poz. 28.

55 Niezidentyfikowane wydanie z tą datą. Być może błąd inwentaryzującego lub nieznany przedruk wydania czwartego z $1804 \mathrm{r}$.

56 I.e. Gavanti.

57 Estr. XV-XVIII, t. 17, s. 41.

58 Estr. XV-XVIII, t. 27, s. 344.

59 Estr. XV-XVIII, t. 24, s. 275.

60 Estr. XV-XVIII, t. 19, s. 182.

61 Estr. XIX, t. 2, s. 430.

${ }^{62}$ Autor: Franciszek Giftschütz. Estr. XIX, t. 2, s. 34.

63 Estr. XV-XVIII, t. 21, s. 119.

${ }^{64}$ Autor : Józef Jakuowski. Estr. XIX nie notuje. 
Księgozbiór karmelitów dawnej obserwancji w Sąsiadowicach

\begin{tabular}{|c|c|}
\hline 44. & Comentaria in apocalipsim - Haymonis. Kolonia $1531^{65}$. \\
\hline 45. & Scholia in Eplas S. Pauli - Joan. Gagnio Parisi $1563^{66}$. \\
\hline 46. & Suma Teolog. scholast. - Martini Bacani Lugduni 1739. \\
\hline 47. & Instructorii conscientiae - Lud. Lopez Lugduni $1587^{67}$. \\
\hline 48. & Teologia moralis - wydanie Krakowskie bez tytułu i roku. \\
\hline 49. & Nauka dla młodych spowiedników. Pawł. Segner. Wilno $1740^{68}$. \\
\hline 50. & Das kat. Glaubens-Princip - Thomas Ziegler Wien 1823. \\
\hline 51. & Teologia moralis - Vencesl. Schanza - Vindob. 1785. \\
\hline 52 & Teologia pastoralis - Jos. Lauber - Viennae 1782. \\
\hline 53. & Authoritatum S. Scriptura et S.S. Patrum - Petri Canisii - 2 tomy - Colonia $1569^{69}$. \\
\hline 54. & Praelectiones theol. Tournely Honor. Venetiis 1746. \\
\hline 55. & Via vitae aeternae - Ant. Sucquet - Antverpia 1624. \\
\hline 56. & Casus conscientiae - Bened. XIV Premysliae $1766^{70}$. \\
\hline 57. & $\begin{array}{c}\text { Appendix ad casum conscientiae - [skreślono:] Lopez Ludov. Styrae } 1738 \text { [dopisano } \\
\text { u góry:] Ibidem. }\end{array}$ \\
\hline 58. & Instructorii conscientiae - Lopez Ludv. Styrae 1738. \\
\hline 59. & Institutiones suae - 2 tomy. Ludovici Danes $1587^{71}$. \\
\hline 60. & Manuale Tomistarum - Joan. Gonet - Patavii 1757 - 3 tom jeden brakuje. \\
\hline 61. & Dyalogi B. Gregorii-Colonia 1610. \\
\hline 62. & Teologia moralis juxta Divi Thomae Dogmata - (bez tytułu i roku). \\
\hline 63. & Notitia conciliorum - Joan. Cabasutio Viennae 1738. \\
\hline
\end{tabular}

65 Ossol. XVI.O.8881. Zob. Knyhozbirnya, s. 44, poz. 29.

66 Ossol. XVI.O.9292. Zob. Knyhozbirnya, s. 43, poz. 25.

67 Ossol. XVI.O.9579-9580. Zob. Knyhozbirnya, s. 47, poz. 42.

68 Estr. XV-XVIII, t. 27, s. 346.

69 Ossol. XVI.Qu.11415. Zob. Knyhozbirnya, s. 39, poz. 13.

70 Estr. XV-XVIII, t. 14, s. 83.

71 Inwentaryzujący pomylił adresy wydawnicze pozycji 57 i $58 . \mathrm{W}$ rzeczywistości Institutiones Danesa wyszły w Styrze (Grecja) w 1738 r., a Instructorium conscientiae Lopeza w 1587 r. w Lyonie. 
Agnieszka Franczyk-Cegła

\begin{tabular}{|c|c|}
\hline 64. & Conferentiae theol. Morales - Eliseus Sargar. Vindel. 1732. \\
\hline 65. & Elucidatio in confiteor - Guielmi Pepin. Venetiis 1592. \\
\hline 66. & De Sacramento Eucharistiae - Rabanus Coloniae $1551^{72}$. \\
\hline 67. & Monita de officis confesarii - Cracoviae $1753^{73}$. \\
\hline 68. & Medulla Theologiae - Busenbaum Herman Sandomiriae 1753 - 2 tomy $^{74}$. \\
\hline 69. & Examen Ordinandorum - Erasmi Preis ${ }^{75}$ - Basani $1770^{76}$. \\
\hline 70. & Neo Confessarius - Joan. Reuter - Col. 1763. \\
\hline 71. & Tribunalis confesariorum Ludovici Thieger - Venetiis 1734. \\
\hline 72. & Praxis Sacr. Poenitentia - Lud. Hobert ${ }^{77}$ Bassani 1770. \\
\hline 73. & Tractatus Evang. Hieronimi de la Nara - Col. Agrippinae 1618. \\
\hline 74. & Censura Prophetiorum ${ }^{78}$ - Greg. Gengeli Leopoli $1724^{79}$. \\
\hline 75. & Teologia mor univ. Philippi Carboneano Romae 1747. \\
\hline 76. & Summa juris canonici (bez początku i końca). \\
\hline 77. & Manuale confesarii - Franz. Herzig - Vratislaviae $1729^{80}$. \\
\hline 78. & Decreta S. Sedis Apostolicae - Mauri Rostkowski - Leopoli $1731^{81}$. \\
\hline 79. & Examen Ordinandorum - Ladis. Sennyei Col. Agrip. 1730. \\
\hline 80. & Moralis Theologia - (bez tytułu). \\
\hline 81. & Methodus expeditae confessionis - Thomae Tambarini - Romae 1650. \\
\hline 82. & Examen Ordinandorum Coloniae 1609. \\
\hline
\end{tabular}

72 Ossol. XVI.O.8409. Zob. Knyhozbirnya, s. 45, poz. 35.

73 Estr. XV-XVIII, t. 22, s. 532.

74 Estr. XV-XVIII, t. 14, s. 465.

75 I.e. Francisci Erasmi Preiss.

76 Wydanie niezidentyfikowane.

77 I.e. Habert.

78 I.e. Prophetiarum.

79 Estr. XV-XVIII, t. 17, s. 92.

80 Estreicher nie notuje.

81 Autor: Jan Kery. Estr. XV-XVIII, t. 19, s. 232. 
Księgozbiór karmelitów dawnej obserwancji w Sąsiadowicach

\begin{tabular}{|c|c|}
\hline 83. & Summa Comentariorum - Marci Serrae Romae 1653. \\
\hline 84. & Manuductio ad rito celebrandum - Andreae Jordan Leopoli $1773^{82}$. \\
\hline $84[!]$. & Elementa ad S. Confessiones - Nicolai Mosciscensis - Cracoviae $1602^{83}$ \\
\hline 86. & Sposób dla spowiedników - Tylkowskiego - Lwów $1760^{84}$. \\
\hline 87. & Decreta S. Sedis Apost. - Joan. Kery - Częstochoviae $1694^{85}$. \\
\hline 88. & Theologia uniwersa. T. 7mus. - Thomis de Charmes - Nancei 1763. \\
\hline 89. & Examen confesariorum - Greg. Schoeavert ${ }^{86}$ - Coloniae $1722^{87}$. \\
\hline 90. & Epitomae $^{88}$ doctrinae moralis - Joan. Dom Mausi Vindel. 1765. \\
\hline 91. & Dialogi elucidatorii - Albert Krotkowicz - Cracoviae $1549^{89}$. \\
\hline 92. & Libri senten. De summo bono. S. Isidori Hispalensis - Antverpiae 1560. \\
\hline 93. & Instructio confess. ( - bez tytułu i końca). \\
\hline 94. & Clypeus Turris David. - Leopol $1744^{90}$. \\
\hline 95. & Loci communes - Joan. Hofmeister - Antverpiae 1550. \\
\hline 96. & Compendium manualis Navarri - Romae 1590. \\
\hline 97. & Institutiones Theologicae - Petri Collet. Culmae 1765 - 3 tom. \\
\hline 98. & Institutiones Hermeneuticae - Damiani Czerny - Brunae 1782. \\
\hline 99. & Praelectiones theol. - Petri Gazzaniga - Romae 1769. \\
\hline 100. & Theologia compendium ${ }^{91}$. Gasparis Juenin Antverpiae 1759. \\
\hline
\end{tabular}

82 Estr. XV-XVIII, t. 22, s. 623.

83 Estreicher notuje dwa wydania w 1603 r., w tym drugie z wyrażoną na stronie tytułowej edycją: „Editio secunda et correcta”. Zob. Estr. XV-XVIII, t. 22, s. 583.

${ }^{84}$ Autor: Paul Segner. Wojciech Tylkowski był thumaczem. Estr. XV-XVIII, t. 27, s. 347.

85 Estr. XV-XVIII, t. 19, s. 232.

86 I.e. Schoonaerts.

87 Wydanie niezidentyfikowane.

88 I.e. Epitome.

89 Ossol. XVI.O.1026. Zob. Knyhozbirnya, s. 36, poz. 2.

90 Estr. XV-XVIII, t. 22, s. 477.

91 I.e. Theologia redacta in compendium. 
Agnieszka Franczyk-Cegła

\begin{tabular}{|c|c|}
\hline 101. & Innocentia B.V. Mariae vindicate - Coelestini Sfondrati - Sandomiriae $1758^{92}$. \\
\hline 102. & Theologia dogmatica - (bez tytułu i końca). \\
\hline 103. & Breviarium universae Theologiae - Antoni Gavelli - Cracoviae $1722^{93}$. \\
\hline 104. & Veritas fidei Christianae - Erasmi Preis ${ }^{94}$ - Sandomiriae $1788^{95}$. \\
\hline 105. & De Divinis et Traditionalibus - Martini Ayala - Coloniae $1560^{96}$. \\
\hline 106. & Cursus Theologiae abbreviates - Anselmi Schnell - Aug. Vindel 1747. \\
\hline 107. & De summo pontifice - Roberti Belarmini. \\
\hline 108. & Theologia universalis. Tom 1. Thomae ex Charmes - Nanceii 1763. \\
\hline 109. & Theologia biblica - Henrici a Diest. 1643. \\
\hline 110. & Confessionale Dni-Ant. Archeppi Florentini - Argentinae $1496^{97}$. \\
\hline 111. & De sacris diebus - Jacobus Vimphelingius 1518. \\
\hline 112. & Theologia moralis - Anacleti Reifenstuel Venetia 1722. \\
\hline 113. & Theologia universalis - Gabr. Antoine - Aug Vindelicor 1755 - 3 tomy. \\
\hline 114. & Suma quaestionum regularium Tom V Joan de Lezaner ${ }^{98}$ - Romae 1647. \\
\hline 115. & Institutiones Dogmaticae - Engelberti Klüpfel - Viennae 1803. \\
\hline 116. & Breviarium scripturisticum Tom II et III. Tyrnaviae 1746. \\
\hline 117. & Theologia polemica Tom. II - Petri Garraniga Viennae 1779. \\
\hline 118. & Dialogion de fide - Dionisi Carthusiani - Coloniae 1534. \\
\hline 119. & Flosculi omnium materiarum ( - bez tytułu i końca). \\
\hline
\end{tabular}

92 Estr. XV-XVIII, t. 27, s. 419.

93 Estr. XV-XVIII, t. 17, s. 43.

94 I.e. Francisci Erasmi Preiss.

95 Estr. XV-XVIII, t. 25, s. 234.

96 Ossol. XVI.O.9063. Zob. Knyhozbirnya, s. 51, poz. 56.

97 Incunabula quae in bibliothecis Poloniae asservantur $=$ Inkunabuly $w$ bibliotekach polskich, t. 1-2, red. A. Kawecka-Gryczowa, oprac. M. Bohonos, M. Szandorowska, Warszawa 1970 (dalej: IBP) 410. Incunabula Short Title Catalogue online, https://data.cerl.org/istc/ (dalej: ISTC) ia00829000. Egzemplarz BKKr, sygn. XV.41.

98 I.e. Lezana. 
Księgozbiór karmelitów dawnej obserwancji w Sąsiadowicach

\begin{tabular}{|c|c|}
\hline 120. & O gruncie religii. Tom. I. Ant. Walseki - Berdyczów $1777^{99}$. \\
\hline 121. & Theologia moralis - Edmundi Voit. Wircenburgii - 1760. \\
\hline 122. & Catechesus ex temporanea. \\
\hline 123. & Katechizm Katolicki podlug Niemieckiego Schmidta - Poznań $1839^{100}$. \\
\hline 124. & $\begin{array}{c}\text { Etyka chrześciańska - Ant. Reybergera na polsk. W } 3 \text { tomach przez } \\
\text { Jana K. Chodaniego - Wilno - } 1821^{101} \text {. }\end{array}$ \\
\hline 125. & Kazania 8-dniowe przy sprowadzeniu N.M.P. w Częstochowie $1784^{102}$. \\
\hline 126. & 3 Kazania piatkowe o męce Panskiej. Sieriewicza Adryana - Lwów $1727^{103}$. \\
\hline 127. & Kazanie o poszanowaniu duchownych i inne. Woyciech Zabielski - Lublin $1755^{104}$. \\
\hline 128. & Collectio concionum Angl. Jordan. \\
\hline 129. & Kazania świąteczne - Adama Będkowskiego. Kalisz 1779. ${ }^{105}$ \\
\hline 130. & Kazania przygodne Tegoż samego - $1786^{106}$. \\
\hline 131. & Kazania postne. Józefa Haberkorna Kalisz $1785^{107}$. \\
\hline 132. & Dwa kazania dla zakonników - Przemyśl $1767^{108}$. \\
\hline 133. & Litera pastorales - Eppi Lucoviensis et Brestaviensis 1742. \\
\hline 134. & Kazania różne - ks. Kowalewskiego ${ }^{109}$ - Przemyśl 1826. 2 tom ${ }^{110}$. \\
\hline 135. & Homilii tegoż - Przemyśl 1830. Roczników $4^{111}$. \\
\hline
\end{tabular}

$99 \quad$ Estr. XV-XVIII, t. 32, s. 183.

100 Estreicher notuje wydanie z 1840 r. Estr. XV-XVIII, t. 4, s. 198.

101 Estr. XIX, t. 4, s. 36.

102 Estr. XV-XVIII, t. 14, s. 574.

103 Estr. XV-XVIII, t. 27, s. 394-395.

104 Estr. XV-XVIII, t. 24, s. 26.

105 Estr. XV-XVIII, t. 12, s. 431.

106 Estr. XV-XVIII, t. 12, s. 431.

107 I.e. Kazania o tajemnicach męki Zbawiciela, t. 2. Estr. XV-XVIII, t. 18, s. 3.

108 Autor: Grzegorz Piramowicz. Bez wyrażenia miejsca i daty wydania na stronie tytułowej. Estr. XV-XVIII, t. 24, 308.

109 I.e. Kawalewskiego.

110 Estr. XIX, t. 2, s. 368.

111 Estr. XIX, t. 2, s. 369. 
Agnieszka Franczyk-Cegła

\begin{tabular}{|c|c|}
\hline 136. & Katedra niedzielnego kaznodzieie - Franc. Kowalicki - Cracoviae $1718^{112}$. \\
\hline 137. & Homilien auf die Festtage - Joh. Schneid Regensburg 1838. \\
\hline 138. & Kazania postne i na niektóre okoliczności $i^{113}$. \\
\hline 139. & Kazania na święta i pasye - Kasyana Korczyńskiego Kraków 1767 - 2 tomy ${ }^{114}$. \\
\hline 140. & Kazania - Barnaby Kędzierskiego - Lwów 1770.3 tom ${ }^{115}$. \\
\hline 141. & Concionator Extemporaneus - Affonsi Beer - Aug. Vindel. 1759. \\
\hline 142. & Kazania niedzielne - Teodora Grubera - Częstochowa $1778^{116}$. \\
\hline 143. & Kazania piątkowe w poście - Gracyana Piątkowskiego ${ }^{117}$ - Warszawa $1770^{118}$. \\
\hline 144. & Kazania przygodne - ks. S.J. de Segaud. Kalisz $1784^{119}$. \\
\hline 145. & Mowy parafialne - Tomasz Grodzicki Warszawa 1795 - tomów 4 (2i brakuje) ${ }^{120}$. \\
\hline 146. & Kazania świateczne pośmiertne. Jakób Filipowicz. Poznań $1737^{121}$. \\
\hline 147. & Kazania niedzielne - ks. Karpowicz ${ }^{122}$. \\
\hline 148. & „, , Koenigsdorfera Augsburg $1837-2$ tomy. \\
\hline 149. & Kazanie na cześć N.P. - Antoni Węgrzynowicz. Kraków $1704^{123}$. \\
\hline
\end{tabular}

112 Estreicher notuje jedynie edycję drukowaną w Sandomierzu w 1725 r., w którym jest aprobata podpisana „Cracoviae 16. Octob. 1718”. Por. Estr. XV-XVIII, t. 20, s. 171.

113 Zob. Estr. XV-XVIII, t. 21, s. 50.

114 Estr. XV-XVIII, t. 20, s. 83-84.

115 Estreicher notuje wydanie 4-tomowe z 1772 r. Estr. XV-XVIII, t. 19, s. 223.

116 Estr. XV-XVIII, t. 17, s. 422.

117 I.e. Piotrowskiego.

118 Estr. XV-XVIII, t. 24, t. 301-302.

119 Elektroniczna Baza Bibliografii Estreichera online (dalej: EBBE online) notuje jedynie tytuł Krotkie zebranie wszystkich Kazań W. X. de Segaud S. J. z francuzkiego zebrane i na oyczysty język przełożone przez X. Wawrzyńca Dunina pod hasłem Sagaud. W tym roku w Kaliszu wyszły także Kazania przygodne przez kapłana w przypisie wyrażonego, także y innych nie wyrażonych po różnych mieyscach miane autorstwa Jana Górskiego - ani na stronie tytułowej ani w treści nie jest wymieniony Segaud. Estr. XV-XVIII, t. 17, s. 264.

120 Estr. XV-XVIII, t. 17, s. 392.

121 Estr. XV-XVIII, t. 16, s. 220.

122 Najprawdopodobniej Kazania niedzielne Maksymiliana Karpowicza wydane w Warszawie przez Michała Grölla w 1770 r.

123 I.e. Melodya s. Kazimierza ... albo pieśń o Nayświętszej Pannie Maryi. Estr. XV-XVIII, t. 32 , s. 309 . 
Księgozbiór karmelitów dawnej obserwancji w Sąsiadowicach

\begin{tabular}{|c|c|}
\hline 150. & Kazania niedzielne - Józef Męciński Kraków 1782 - 3 tomy ${ }^{124}$. \\
\hline 151. & Kazania świąteczne Tegoż $1787-2$ tomy $^{125}$. \\
\hline 152. & „przygodne, $1788^{126}$. \\
\hline 153. & Nauki wiejskie „, 18022 tomy ${ }^{127}$. \\
\hline 154. & Dyalog męki Ch[rys]t[uso]wej ${ }^{128}$ - Adryana Seriewicza. Lwów 1738. ${ }^{129}$ \\
\hline 155. & $\begin{array}{l}\text { Kazania niedzielne i świąteczne - Antoni Janiszewski Berdyczów } 1779 \text { - tom. } \\
2.3 \cdot 4^{130} \text {. }\end{array}$ \\
\hline 156. & Sonntagspredigten von Bauerschubert Josef - Gratze $1802-3$ tomy. \\
\hline 157. & Sonntags und Festpredigten kurz und güt (Bez tytułu i roku). \\
\hline 160. & Kazania - Andrzej Filipecki - Lwów $1784^{131}$. \\
\hline 158. & Kazania. Karol Fabiani Kalisz $1790 .{ }^{132}$ \\
\hline 159. & " na święta odpusty i pogrzeby Łowicz $1802^{133}$. \\
\hline 161. & Haus Postille. And. Stöckel - Wien 1823. \\
\hline 162. & Kazania postne. Józef ks. Lancucki Warszawa $1784^{134}$. \\
\hline 163. & Kazań trzy Jan Kowalski Lwów1776 135 . \\
\hline 164. & Nauki religijne. Wrocław $1822^{136}$. \\
\hline 165. & Homilie niedzielne - Alfonso de Ligorio Warszawa $1783^{137}$. \\
\hline
\end{tabular}

124 Estr. XV-XVIII, t. 22, s. 254.

125 Estr. XV-XVIII, t. 22, s. 254-255.

126 Estr. XV-XVIII, t. 22, s. 254.

127 Estr. XIX, t. , s. 90.

128 I.e. Jezusowej.

129 Estr. XV-XVIII, t. 27, s. 392-393.

130 Estr. XV-XVIII, t. 18, s. 452.

131 Estr. XV-XVIII, t. 16, s. 218.

132 Estr. XV-XVIII, t. 16, s. 153.

133 Estr. XIX nie notuje.

134 Estr. XV-XVIII, t. 21, s. 50.

135 Estreicher nie notuje.

136 I.e. Kazania czyli krótkie nauki religijne. Estr. XIX, t. 3, s. 369.

137 Estr. XV-XVIII, t. 21, s. 273. 
Agnieszka Franczyk-Cegła

\begin{tabular}{|c|c|}
\hline 166. & Kazania moralne z francuzkiego - Kazim. Gołecki - Poznań $1801^{138}$. \\
\hline 167. & Fastenpredigten. Franc. Neumarck - Augsburg 1771. \\
\hline 168. & Gast- und Gelegenheits-Predigten Aegidius Jais - Salzburg 1848. \\
\hline 169. & Kazania Arcyb. Ignacego Krasickiego Warszawa $1819^{139}$. \\
\hline 170. & Homilietische Predigten - Ludwig Stoissing ${ }^{140}$ Linz 18414 tomy. \\
\hline 171. & Odezwy pasterskie. Winc. Frydrych Przemyśl $1830^{141}$. \\
\hline 172. & Chwata Maryi - Ziembicki - Lwów $1764^{142}$. \\
\hline 173. & Kazania niedzielne - Józef Haberkorn ${ }^{143}$. \\
\hline 174. & Post staropolski - Franc. Walicki ${ }^{144}$ Sandomierz $1718^{145}$. \\
\hline 175. & Kazanie niedzielne Konst. Awedyk ${ }^{146}$. \\
\hline 176. & „, „, i Świat. Bonawent. Golanowski ${ }^{147}$ Toruń $1727^{148}$. \\
\hline 177. & Kazania niedzielne świąt i jubileuszowe Paweł Winnicki - Warszawa $1838^{149}$ \\
\hline 178. & Predigten des ganzen Jahres Ferd. Ortman - Wien 1798. \\
\hline 179. & Volspredigten - Mich. Herman - Prag 1809. \\
\hline 180. & Erklärungen der H. Evang. Paul Jais Grätz 1824. \\
\hline 181. & Deutsche Evangelien. \\
\hline 182. & Kazania niedzielne od kartki 17. \\
\hline
\end{tabular}

138 Autor: Joseph-François Lafitau. Kazimierz Gołecki był tłumaczem. Estr. XIX, t. 2, s. $542-543$.

139 Estr. XIX, t. 2, s. 468.

140 I.e. Stroissnigg.

141 Estr. XIX, t. 1, s. 521.

142 Estr. XV-XVIII, t. 35, s. 353.

143 Najprawdopodobniej wydanie kaliskie z 1781-1783 r. Estr. XV-XVIII, t. 18, s. 3.

144 I.e. Kowalicki.

145 Estr. XV-XVIII, t. 20, s. 172.

146 Najprawdopodobniej wydanie lwowskie z 1766 r. Estr. XV-XVIII, t. 12, s. 310.

147 I.e. Gelarowski.

148 Estr. XV-XVIII, t. 17, s. 79.

149 Estr. XIX, t. 5, s. 99. 
Księgozbiór karmelitów dawnej obserwancji w Sąsiadowicach

\begin{tabular}{|c|c|}
\hline 183. & , , Jędrzej Marczyński Sandom $1783^{150}$. \\
\hline 184. & Homilie i materye kazań - Samuel Wysocki Warszawa 1762 - 3 tomy ${ }^{151}$. \\
\hline 185. & Nauki paraf. Ks. Jan Paweł Woronicz Tom I Kraków $1829^{152}$. \\
\hline 186. & Gospodyni nieba i ziemi - Jacek Liberiusz - Kraków 1657 (litog. foth. ${ }^{153}$ \\
\hline 187. & Kazania rozmaite - Józef Wereszczeński Kraków 1587 (litog. goth.) ${ }^{154}$. \\
\hline 188. & Rok odkupienia - ks. Marian od św. Stanisława - Lwów $1747^{155}$. \\
\hline 189. & Sonnlagspredigten. \\
\hline 190. & Homilien der höhern Gattung - Franc Joseph Zenger Sulzbach 1823. \\
\hline 191. & Kazania różne. Sebastian Zacharski Przemyśl $1804^{156}$. \\
\hline 192. & Predigten und Homilien - Sebast. Mutschelle München 1813. \\
\hline 193. & Predigten über den Inhalt der s. Evangelien Wien 1799. \\
\hline 194. & Kazania Sebastian Lachowski Tom I Warszawa $1770^{157}$. \\
\hline 195. & Predigten für das Landvolk - II Bd. Wien 1776. \\
\hline 196. & Fastenpredigten - Vit. Schaefer - Glatz 1705. \\
\hline 197. & Chwała Bogu - Stanił. Mamczyński - Poznań $1737^{158}$. \\
\hline 198. & Kazania niedzielne - Ant. Glazyński. Nieświz 17793 tomy ${ }^{159}$. \\
\hline 199. & Son und Festpredigten - Beda Mayrs - Augsburg 17873 tomy ${ }^{160}$ \\
\hline
\end{tabular}

${ }^{150}$ Najprawdopodobniej pomyłka w druku, Estreicher notuje jedynie wydanie z $1753 \mathrm{r}$. Estr. XV-XVIII, t. 22, s. 630-631.

151 Estr. XV-XVIII, t. 33, s. 467.

152 Estr. XIX, t. 5, s. 159.

153 Estr. XV-XVIII, t. 21, s. 261.

154 I.e. Kazania albo ćwiczenia chrześcijańskie. Estr. XV-XVIII, t. 32, s. 350.

155 I.e. Sikorski Marian. Estr. XV-XVIII, t. 28, s. 92.

156 Estricher nie notuje wydania z tą datą. Por. wydanie z 1807 r.: Estr. XIX., t. 5, s. 224.

157 Estr. XV-XVIII, t. 21, s. 12.

158 Estreicher nie notuje wydania z tą datą. Por. wydanie z 1738 r.: Estr. XV-XVIII, t. 22, s. 105.

159 Estr. XV-XVIII, t. 17, s. 163.

160 I.e. Predigten über den Catechismus für das Landvolk auf alle Sonn- und Festtage des Jahres, t. 1-3, Augsburg 1778. 
Agnieszka Franczyk-Cegła

\begin{tabular}{|c|c|}
\hline 200. & Predigten über den Katechismus „„, 1781. \\
\hline 201. & Sonn- und Fastenpredigten - Sebast. Winkelhofer Regensburg $1839-2$ tomy $^{161}$. \\
\hline 202. & Conc. de festis Tom IV Beda Mayrs 1781. \\
\hline 203. & Predigten eines Dorfpfarrers - Edelbert Menne - Regensburg 1844. 2 tomy ${ }^{162}$. \\
\hline 204. & Zbiór kazań przygodnych - Waler Szawelski Częstochowa $1782^{163}$. \\
\hline 205. & Fastenpredigten - Haberkorn - Gratz 18342 tomy. \\
\hline 206. & Pastoral Anthropologie - Math. Macher Leipzig 1838. \\
\hline 207. & Gratulatoria carmina - Viennae $1558^{164}$. \\
\hline 208. & Firmamentum simbolicum - Sebast. Carm. - Lublini $1662^{165}$. \\
\hline 209. & Explanatio regulae Carmelitarum - Thom. Paglisius ${ }^{166}$ - Neapoli 1707. \\
\hline 210. & Synodus Poznaniensis - Varsoviae $1720^{167}$. \\
\hline 211. & Ser. Cap. Gen. ordinis Nostri - Engelbert Carm. eremit. ${ }^{168}$ Romae 1765. \\
\hline 212. & Synodus provincialis Ruthenorum Romae 1724. \\
\hline 213. & Zbiór krótkich wszystkich umiejętności C. 2 Wrocław $1804^{169}$. \\
\hline 214. & Encyclopedia filologica. Samuel Kaulfus ${ }^{170}$ Vratislaviae $1805^{171}$. \\
\hline
\end{tabular}

161 I.e. dwa z sześciu tomów dzieła pt. Sebastian Winkelhofers zusammenhängende Predigten.

162 I.e. Leichtfaßliche Predigten eines Dorfpfarrers an das Landvolk, auf alle Sonn- und Festtage.

163 Estr. XV-XVIII, t. 30, s. 214.

164 I.e. Carmina duo gratuatoria scripta in honorem ... Christophori Greuuelij Gribsuualdensis.../ A Wolfgango Benekendorpio, \& Hieronymo Birckholtz Marchicis.

165 Najprawdopodobniej pomyłka inwentaryzującego, druk wyszedł w 1652. Estr. XV-XVIII, t. 27 , s. 328 .

166 I.e. Puglisius.

167 Estr. XV-XVIII, t. 30, s. 150.

168 I.e. Brevis series omnium capitulorum generalium in ordine B[eatissi]mae semperque Virginis Mariae de Monte Carmelo habitorum ... / in lucem edita A F.P. Engelberto A S. Francisca.

169 Estr. XIX, t. 10, s. 13.

170 I.e. Encyclopaedia philologica Johanna Samuela Kaulfussa.

171 Estreicher notuje jedynie wydanie w języku polskim z 1814 r. Estr. XIX, t. 2, s. 368. 
Księgozbiór karmelitów dawnej obserwancji w Sąsiadowicach

\begin{tabular}{|c|c|}
\hline 215. & Feuerwerkerkunst für Dilettanten - Bikner ${ }^{172}$ Breslau $1823^{173}$. \\
\hline 216. & Apophtegmata. Anegdoty dawnych Polaków Kraków ${ }^{174}$. \\
\hline 217. & Doświadczenia w gospodarstwie - Kraków 1801 - 2 tomy ${ }^{175}$. \\
\hline 218. & Dworzanin - lit. goth. - brak początku i końca ${ }^{176}$. \\
\hline 219. & Dzieje Polski - Joachim Lelewel - Warszawa $1830^{177}$. \\
\hline 220. & Pielgrzymka do Ziemi św. - Józef Drohojowski Kraków 1812 - 2 tomy ${ }^{178}$. \\
\hline 221. & Szkoła świata - z francuzkiego - Warszawa $1778^{179}$. \\
\hline 222. & Teatrum historicum - Matthei Tympii Viennae 1625. \\
\hline 223. & Amerykanie. Tragedya. - Manuskrypt Warszawa $1750^{180}$. \\
\hline 224. & Historye rozmaite - Manuskrypt - 1739. \\
\hline 225. & Pompa Casimiriana - Grzeg. Świecicki - $1600^{181}$. \\
\hline 226. & Selecta latini sermonis. - Viennae 1781. \\
\hline 227. & Idzi Blas niemiecki - Kraków - 3 tomy $-1798^{182}$. \\
\hline 228. & Disertationes medicin. - Dni Alberti - Vitebergiae - 1590. \\
\hline
\end{tabular}

172 I.e. Friedrich Christian August Büttner.

173 Estreicher nie notuje.

174 Najprawdopodobniej Krótkie przypowieści dawnych Polaków czyli Apophtegmata anegdoty itp z dawnych ksiag i rękopisów zebrane Ambrożego Grabowskiego i Hieronima Juszyńskiego, wydane w Krakowie w 1819 r. Estr. XIX, t. 2, s. 72.

175 Estr. XIX, t. 1, s. 335.

176 Wydanie z 1566 lub 1639 - oba drukowano gotykiem. Estr. XV-XVIII, t. 17, s. 252-253.

177 Estr. XIX, t. 2, s. 564.

178 Estr. XIX, t. 1, s. 415.

179 Autor: Eustache Le Noble. Estr. XV-XVIII, t. 21, s. 175-176.

180 Pierwszy polski przekład dzieła Alzire ou les Américains Voltaire'a pt. Alcyra wyszedł drukiem dopiero w $1754 \mathrm{r}$. W roku 1750 Alcyra wystawiana była przez uczniów szkoły pijarskiej, $\mathrm{z}$ czego zachował się drukowany program pt. Amerykanie. Tragedya $w$ Warszawie 1750 pod czas Karnáwału w Kollegium Jch Mciow. Konwiktorow Scholarum Piarum reprezentowana. Zob. Estr. XV-XVIII, t. 33, s. 307-308.

181 Estreicher nie notuje wydania z tego roku. Pompa Casimiriana byłą jedną z części dzieła Święcickiego pt. Theatrum S. Casimiri wyd. w Wilnie w 1604 r. (s. 39-127). Zob. Estr. XV-XVIII, 30, 88-89.

182 Autor: Adolf von Knigge. Estr. XV-XVIII, t. 19, s. 344. 
Agnieszka Franczyk-Cegła

\begin{tabular}{|c|c|}
\hline 229. & Gramatica latina cum catechismo - Canisi. \\
\hline 230 . & Traktat Rabina Samuela - Jakób Radliński Kraków [1]732 183. \\
\hline 231. & Gramatyka francuzko polska - Warszawa $1750^{184}$. \\
\hline 232. & Monitor - przyjemne i zabawne czytanie $1766^{185}$. \\
\hline 233. & Praecepta selecta de agricultura - Const. Caesar Venetiae 1535. \\
\hline 234. & Magie, oder, die Zauberkräfte der Natur Jos.Halle ${ }^{186}$ Wien 1785. \\
\hline 235. & Rzeczy ciekawe rozmaite - Manuskrypt. \\
\hline 236. & Dykcyonarz lac. Polski - Knapiusz $1622^{187}$. \\
\hline 237. & Valerii Maximi, Livi Flori et Pompaenii memorabilia - Romae $1511^{188}$. \\
\hline $138[!]$. & Antiquitas ordinis B.M.V. de monte Carmelo - Sebast. Carmelo. Frankfurtii ${ }^{189}$ \\
\hline $139[!]$. & Monologium Carmelitarum - Petro de Bononia Carm - Bononia 1627. \\
\hline 240. & De aggeribus et pontibus - P. Bertii - Parisis 1629 . \\
\hline 241. & Gramatica latina et vocabularium. Argentinae $1491^{190}$. \\
\hline 242. & Curiosa varii generis - Manuskrypt. \\
\hline 243. & Lechus - historia Poloniae restitutus - Stanisl. Kleczewski - Olomuncii $1774^{191}$. \\
\hline 244. & $\begin{array}{c}\text { Epitaphia - [skreślono:]Olom [pozostawiono:]joci seria - Franc. Severtius }{ }^{192} \text { Colo- } \\
\text { niae } 1623 .\end{array}$ \\
\hline
\end{tabular}

183 Autor: Samuel Rabi Marokański. Jakub Radliński był tłumaczem. Estreicher nie notuje wydania z 1732 r. ani tez żadnego wydania krakowskiego. Por. Estr. XV-XVIII, t. 27, s. 60-61.

184 Autor: Stanisław Dąbrowski. Estr. XV-XVIII, t. 15, s. 5-6.

185 Estr. XV-XVIII, t. 12, s. 225 (Bohomolec); t. 22, s. 533-534 (Monitor).

186 I.e. Johann Samuel Halle.

187 Estreicher nie notuje wydania z tą datą. Por. edycję z 1621 r.: Estr. XV-XVIII, t. 19, s. 334.

188 Wydanie niezidentyfikowane.

189 I.e. Libellus supplex sanctissimo domino Innocentio 11. pro origine et antiquitate ordinis Carmelitarum, ... adversus P. Danielem Papebrochium soc. Iesu, eas ut commenta \& imposturas explodentem, exhibitus per F. Sebastianum à S. Paulo provincialem provinciae Flandro-Belgicae..., Francofurti : apud viduam Zubrodt, 1683.

190 I.e. Reuchlin Ioannes, Vocabularius breviloquus, Strassburg: [Typogr. Jordani Ge. Husner], 26 VII 1491. IBP 4745. ISTC ir00167500. Być może egzemplarz BKKr, sygn. XV.160.

191 Estr. XV-XVIII, t. 19, s. 275.

192 I.e. Swertius, Pierre François Sweerts. 
Księgozbiór karmelitów dawnej obserwancji w Sąsiadowicach

\begin{tabular}{|c|c|}
\hline 245. & De caffe, chocolade, Herbae nicotianae - Ferd. Meisner - Nirenbergii 1721. \\
\hline 246. & Rys dziejów kultury i narodu polskiego - Ign. Czerwiński - Przemyśl $1816^{193}$. \\
\hline 247. & Dictionarium polono - lat. Leopoli $1745^{194}$. \\
\hline 248. & Suada civilis - Joannis Kwiatkiewicz. Calisii $1697^{195}$. \\
\hline 249. & Syntagma medicum. - Nicol. Fontano - Amsterdam $1617^{196}$. \\
\hline 250. & Thesaurius ${ }^{197}$ phrasium poeticarum. Joannis Buchler Coloniae 1617. \\
\hline 251. & Ceremoniale Episcoporum, Col. Agrip. 1712. \\
\hline 252. & Compendium universae medicinae - Iust. Cuntii ${ }^{198}$ - Vicentiae $1688^{199}$. \\
\hline 253. & Civilis doctrinae libri sex - Justi Lipsi - Liche ${ }^{200}$. \\
\hline 254. & Trwatość szczęśliwa królestw. C. 3. Szymon Maychrowicz Lwów 1764²01. \\
\hline 255. & Lexykon francusko-polski - Kaz. Malicki ${ }^{202}$ Kraków $1701^{203}$. \\
\hline 256. & Varia carmina - Alb. Ines - Dantisci $1615^{204}$. \\
\hline 257. & Uber die Schönheit der Natur - Georg ${ }^{205}$ Sulzer - Berlin 1774. \\
\hline 258. & Diurnale canonicorum regul. Antwerp 1520. \\
\hline 259. & Officio Parochorum - Joan. Posevini - Mantua 1610. \\
\hline 260. & Itinerarium Frisio Hollandicum - Gotfried Hegenit Lugduniae ${ }^{206}$. \\
\hline
\end{tabular}

193 Estr. XIX, t. 1, s. 274.

194 I.e. Grzegorza Knapskiego Synonima seu dictionarium polono-latinum. Estr. XV-XVIII, t. 19, s. 333.

195 Estr. XV-XVIII, t. 20, s. 427.

196 Bibliografie nie notują wydania Syntagma medicum de morbis mulierum z tego roku. Być może chodziło o 1613 r., a inwentaryzujący mógł machinalnie przepisać datę 1617 z poz. 250.

197 I.e. Thesaurus.

198 I.e. Cnutii.

199 I.e. 1608.

200 Wyd. w $1604 \mathrm{r}$.

201 Estr. XV-XVIII, t. 22, s. 38-39.

202 I.e. Bartłomiej Kazimierz Malicki.

203 Estr. XV-XVIII, t. 22, s. 91.

204 I.e. 1645 lub 1655. Zob. Estr. XV-XVIII, t. 18, s. 570.

205 I.e. Johann Georg.

206 Wydane w Leidzie w 1630, 1661 lub w 1667. 
Agnieszka Franczyk-Cegła

\begin{tabular}{|c|c|}
\hline 261. & Ius publicum Polonum - Nicol. Chwałkowski ${ }^{207}$. \\
\hline 262. & Heilung des Magenkrampfes - Lud. Meiner - Leipzig $1822^{208}$. \\
\hline 263. & Commentaria de Physica ${ }^{209}$ - Mich. Zanardi Venetia 1617. \\
\hline 264. & Fortgesetzte Magie. - Jos. Sam. Halle 11 Bd. Wien 1785. \\
\hline 265. & Elementa Philosophiae - Laur. Altieri - Venetiae 1776 - 2 tomy. \\
\hline 266. & Hieroglyphica - Joan. Pieri $1536^{210}$. \\
\hline 267. & Syntomu [m] in Aristotelis Philosophiam - P. Manolini - Romae $1723^{211}$ \\
\hline 268. & De Eloquentia Manuskrypt. 1672. \\
\hline 269. & Logica - Tom. Genarii - Venet. $1749^{212}$. \\
\hline 270. & De principiis et affectionibus rerum Bened. Pereirus Coloniae 1595. \\
\hline 271. & Ars rhetorica. - Gab. Fran. Le Jays. Venetiae 1748. \\
\hline 272. & Institutiones Philosophicae. - Fran. Jacquier Venet. 1773 - 4 tomy. \\
\hline 273. & Omnia opera in univ. Philosophiam - Peter Tatareti - Venet. 1621. \\
\hline 274. & Cynosura profesorum 213. Mat. Tympii Colon. Agrip. 1626. \\
\hline 275. & Praelectiones ethicae - Ign. Polzer - Olomuncii 1770. \\
\hline 276. & Arytmetyka praktyczna - Warszawa $1793^{214}$. \\
\hline 277. & Philosophia athomistica - Joan. Morasch Ingolstadt. 1727. \\
\hline 278. & Spicilegium philosophicum - Alberti Oswald. Colon Agripinae 1697. \\
\hline 279. & Institutionum poeticarum. \\
\hline
\end{tabular}

207 Wydane w Królewcu w 1676 lub 1683 (i.e. 1684) r.

208 I.e. Die gründlichste und sicherste Heilung des Magenkrampfes und der Magenschwäche I Friedrich Ludwig Meissner.

209 I.e. in octo libros de Physico auditu Aristotelis.

210 Brak wyd. $\mathrm{z}$ tą datą. Być może chodziło o Hieroglyphica sive de sacris Aegyptiorum literis commentarii wyd. w 1556 r. w Bazylei.

211 Wydanie niezidentyfikowane.

212 Logica sive ars cogitandi... Autor wyrażony w imprimatur.

213 I.e. Dormi secure: vel cynosura professorum ac studiosorum eloquentiae.

214 Autor: Szymon Bielski. Estr. XV-XVIII, t. 13, s. 90-91. 
Księgozbiór karmelitów dawnej obserwancji w Sąsiadowicach

\begin{tabular}{|c|c|}
\hline 280. & De alchemia - Pet. Enoch - Ambusone $1607^{215}$. \\
\hline 281. & Institutiones Philosophiae - Edm. Purchatt Pataviae 1751. \\
\hline 282. & Rhetorica institutio - Cracoviae $1752^{216}$. \\
\hline 283. & Erotemata dialect. - Philip. Melanchton - Frankfurtii 1552. \\
\hline 284. & Philosophia - Ant. Gaudin - Venet. 1744. \\
\hline 285. & Virgiliii eglisantis Xtiados ${ }^{217}$ - Alex. Rosei Roterdamiae 1653. \\
\hline 286. & De rebus gestis Alexandri Magni - Quintili Curtii - bez końca i tytułu. \\
\hline 287. & Prodromus Praxeos Chimiatricae - Math. Tilinginii Kintelli $1660^{218}$. \\
\hline 288. & Spicilegium philos. Tom I.us - Alb. Oswaldt. - Col. Agripp. 1697. \\
\hline 289. & Institutione rhetoric. Conradi Dietrich Erfurtiae 1626. \\
\hline 290. & Ciceros Sämmtliche Briefe - Christ. Borheck Wien 1801 - 9 tomów. \\
\hline 291. & Institutiones Metaph. in usum scholar. \\
\hline 292. & De sacro Bosco - Iuntini Florentini - Lugduni $1577^{219}$. \\
\hline 293. & Elementa artis logico-criticae - Ant. Genuensis - Venet. 1762. \\
\hline 294. & Praelectiones fysicae experimentalis. Ig. Jos. Martinowicz. - Leopoli ${ }^{220}$. \\
\hline 295. & Institutiones phil. Edm. Purchatii - Pataviae 1751. Tom 3 i 4. \\
\hline 296. & Progymnasmata aphtonii ${ }^{221}$. \\
\hline 297. & $\begin{array}{l}\text { Philosophiae dogmata. Joan. Dunsii in Scotii } 222 \text { - Jos. Ferrari - Venet - } \\
1768 .-3 \text { tomy. }\end{array}$ \\
\hline 298. & Elegantiarum libri - Laur. Vall. \\
\hline
\end{tabular}

215 Wydanie niezidentyfikowane.

216 Estr. XV-XVIII, t. 32, s. 170.

217 I.e. Evangelisantis christiados.

218 I.e. Tilingii, Rintelii 1674.

219 Ossol. XVI.O.9386. Zob. Knyhozbirnya, s. 43, poz. 26.

220 Wyd. w $1787 \mathrm{r}$.

221 I.e. Aphthonii.

222 Na s. tyt.: Joannis Dunsii Scoti. 
Agnieszka Franczyk-Cegła

\begin{tabular}{|c|c|}
\hline 299. & Philosopia argumentosa - Math. Heimbach Col. Agrip. 1730. \\
\hline 300. & Opisanie matem. i fizyczne ziemi Jan Śniadecki - Wilno $1809^{223}$. \\
\hline 301. & De argumentatione et mor phil. - Hier. Wildenberg - Lubomensis $-1546^{224}$ \\
\hline 302. & Liber Eplarum et diversi generis refut. Henr. Agripa Lugduni $1510^{225}$. \\
\hline 303. & Dialogi et Sermones. Plutarchi - Tom II. \\
\hline 304. & Symphosiacon. \\
\hline 305. & Horologium principum. - Ant. De Guevara. \\
\hline 306. & Consilia sapientiae. \\
\hline 307. & Droga do życia poboznego - Jan Denhoff Kraków ${ }^{226}$. \\
\hline 308. & Cwiczenia zakonne - Dan. Pawłowski - Lwów $1741^{227}$. \\
\hline 309. & Pasionis Domini historia - Joan. Feri - Antverp. 1557. \\
\hline 310. & Medytacye i czytanie dla zakonników. \\
\hline 311. & Filius patiens et mater compatiens. Jacobus Carm 1678. \\
\hline 312. & Institutiones christianae - Franc. Costeri 1586. \\
\hline 313. & Actus interni $i^{228}$ - Wilno $1741^{229}$. \\
\hline
\end{tabular}

223 Estr. XIX, t. 4, s. 298.

224 Fragment dzieła Totius philosophiae humanae in tres partes, nempe in rationalem, naturalem, \& moralem, digestio, wydanego w Bazylei w drukarni Jana Oporyna. W egzemplarzu sąsiadowickiem brak karty tytułowej (miejsce i data wydania według przedmowy: „Ex arce nostra Lubomen. Die 16. Augusti. Anno Domini XLVI") i początku (rozdział De argumentatione rozpoczyna się tyt. nagłówkowym na s. 53). Egzemplarz BKKr, sygn. XVI. 745.

225 Jest to drugi dzieł zebranych Agrippy pt. Henrici Cornelii Agrippae ab Nettesheym, armatae militiae equitis aurati, et iuris utriusque ac medicinae doctoris, opera, wydane ok. $1630 \mathrm{r}$. przez E. Zetznera z fałszywym adr. wyd.: Lugduni : per Beringos fratres. Data 1510 pochodzi z przedmowy.

226 Autor: Franciszek Salezy. Jan Denhoff był thumaczem. Prawdopodobnie wydanie pierwsze z 1769 r., drugie z 1737 r., czwarte z 1756 r., szóste z 1769 r., siódme z 1788 r. lub ósme z 1793 r. Estr. XV-XVIII, t. 16, s. 282-283.

227 Estr. XV-XVIII, t. 24, s. 163.

228 I.e. internos.

229 Autor: Sebastian Bolski. Część druga dzieła Exemplar vitae spiritualis et perfectionis pt. Pars secunda actus internos variarum virtutum complectitur. Estr. XV-XVIII, t. 13, s. 245. 
Księgozbiór karmelitów dawnej obserwancji w Sąsiadowicach

\begin{tabular}{|c|c|}
\hline 314. & Manuale Franciscanorum - Joan Rensinck. - Col 1609. \\
\hline 315. & Meditationes de passione Domini - Fran Costeri - Antverpiae 1587. \\
\hline 316. & De quatuor Novissimis ${ }^{230}$. Dion. Carth. Coloniae 1595. \\
\hline 317. & Vita et gneal. S. Annae - Laut. Coper. ${ }^{231}$ Antverp. 1592. \\
\hline 318. & Nova forma meditationum. - Joan Crasset - Monachii 1715. \\
\hline 319. & Homo paulo mino ${ }^{232}$ ab angelis - Onuf. a S. S. Sacr. Trin ${ }^{233}$. Leopoli $1738^{234}$. \\
\hline 320. & Meditatio super Psalm. Miserere. Hier. Ferrarensis. Leopol. $1729^{235}$. \\
\hline 321. & Myśli wyborne - z franc. ks. Boileau Lwów $1729^{236}$. \\
\hline 322. & Via coeli complenata - Joan. Pinamonti Viennae 1745. \\
\hline 323. & Considerationes variae - (bez tytułu i końca). \\
\hline 324. & Reflexye chrześcijańskie - Franc. Nepueu Lwów Lublini $1792^{237}$. \\
\hline 325. & Recipe Salutare. Cracoviae $1754^{238}$. \\
\hline 326. & Sposób do pobudzenia grzeszników. Tylkowski. Lwów ${ }^{239}$. \\
\hline 327. & Viator christianus. - Cracoviae $1693^{240}$. \\
\hline 328. & Flores sententiarum - Lud. Blosii - Cracoviae $1704^{241}$. \\
\hline 329. & Meditationes S. Augustini et S. Bernardi - Lugduni $1592^{242}$. \\
\hline
\end{tabular}

230 I.e. Liber utilissimus de quatuor hominis, novissimis.

231 I.e. B. Annae Christi Servatoris Nostri aviae maternae ... genealogia et vita.

232 I.e. minor.

233 Na stronie tytułowej autor niewymieniony.

234 Estr. XV-XVIII, t. 18, s. 256.

235 Autor: Hieronim Savonarola. Estr. XV-XVIII, t. 2, s. 170.

236 Estr. XV-XVIII, t. 13, s. 238.

237 Estr. XV-XVIII, t. 233, s. 82.

238 Aut.: Jan od Krzyża Karmelita bosy. Estr. XV-XVIII, t. 18, s. 432.

239 Wydane w 1760 r. Autor: Paul Segner. Wojciech Tylkowski był thumaczem. Estr. XV-XVIII, t. 27 , s. 347.

240 Autor: Antoni Krzesimowski.

241 Estr. XV-XVIII, t. 20, s. 323-324.

242 Ossol. XVI.O.8156. Zob. Knyhozbirnya, s. 36, poz. 3. 
Agnieszka Franczyk-Cegła

\begin{tabular}{|c|c|}
\hline 330. & Disciplina populi Dei. - Flegry ${ }^{243}$. Leop. $1784^{244}$. \\
\hline 331. & Reflexye chrzescijanskie. Franc. Nepueu. 1792. \\
\hline 332. & O źródłach niezbozności T. I. Ant. Walsekki ${ }^{245}$ - Berdyczów $1778^{246}$. \\
\hline 333. & Pecatum sacerdotale ${ }^{247}$. \\
\hline 334. & Dziennik swiętych. Jan Szczep. Grosez Lwów $1744^{248}$. \\
\hline 335 . & Cuda S. Joachima i S. Anny - Warszawa $1755^{249}$. \\
\hline 336. & Zycie S. Alojzego ${ }^{250}$. \\
\hline 337. & Scapulare illustratum et defensum Teop. Raynaud. Romae 1730. \\
\hline 338. & Regula instituti Petrini. Car. Ant. Basso. Vilnae $1707^{251}$. \\
\hline 339. & Ascentica et moralis ${ }^{252}$, Wirenburgii 1740. \\
\hline 340. & Sermones S. Bernardi. \\
\hline 341. & De Angelo custode. Coloniae 1612. \\
\hline 342. & Variae devotiones - E diver. Autor. \\
\hline 343. & Praecationes Hieronimi Savonarole - Lugduni $1536^{253}$. \\
\hline
\end{tabular}

243 I.e. Fleury.

244 Estr. XV-XVIII, t. 16, s. 238.

245 I.e. O gruncie religii czyli czci, lub wierności prawdziwey, y zrźodłach niezbożności.

246 Estreicher notuje wydanie z 1777 r. Estr. XV-XVIII, t. 32, s. 183.

247 Najprawdopodobniej akcedit pt. Peccatum sacerdotale grande nimis, triduum secundum do dzieła Finis primus et ultimus sacerdotis, tridus expensus a venerabili clero Stettenii ad Forum Frigidum, anno MDCCXLII et Riedoeschingae MDCCXLIII, praeside et directore P. Maximiliano Dufrene wyd. w 1743 r. w Konstancji.

248 Estr. XV-XVIII, t. 17, s. 415.

249 Autor: Tomasz z Akwinu. Tytuł właściwy: Anna swięta z swiętym Joachimem godnościa wnuka Pana Jezusa Chrystusa dostoieństwem corki Nayśw: Maryi Panny, zyciem własnym, tudzież Łaskami y cudami, dla nabożnych do siebie chwalebni. To iest historya życia y cudow, swiętych Anny y Joachima. Estr. XV-XVIII, t. 31, s. 199-200.

250 Być może Zywot błogosławionego Aloyzego albo Ludwika Gonzagi autorstwa Virgiliusa Cepariego wydany w Krakowie w 1609 r. Estr. XV-XVIII, t. 14, s. 120.

251 Estr. XV-XVIII, t. 12, s. 404.

252 I.e. Ascentica et moralis doctrinae dives, virtutum schola.

253 I.e. Dominicae Precationis Explanatio wydane w 1546 r. 
Księgozbiór karmelitów dawnej obserwancji w Sąsiadowicach

\begin{tabular}{|c|c|}
\hline 344. & De eucharistia - Lud. Pranadensis. Romae $1581^{254}$. \\
\hline 345. & De sum [m]o bono et soliloquia S. Isidori. \\
\hline 346. & Medytacye rozmaite. \\
\hline 347. & Bellator Christianus. - Math. Bembus Varsoviae $1617^{255}$. \\
\hline 348. & De ascensione mentis ad Deum. Rob. Belarmini. Venetiis 1758. \\
\hline 349. & Instructiones Carmelitarum. Romae 1638. \\
\hline 350. & Schola orationis. - Carm. Poznań $1623^{256}$. \\
\hline 351. & Lavacrum animae - Stan. Grochow. Cracov. $1601^{257}$. \\
\hline 352. & Speculum disciplinae ad Novitios. Vilnae $1752^{258}$. \\
\hline 353. & Manuductio ad praxim - Tiburtii Navar Romae 1714. \\
\hline 354. & Diurnus sacerdotum Cibus - Gasp. Druzbicki - Sandomiriae $1733^{259}$ \\
\hline 355. & Sabbathum Marianum - $1743^{260}$. \\
\hline 356. & Meditationes in passionem. - Venc. Bruno. Col. Agrip. $1598^{261}$. \\
\hline 357. & Soliloquia S. Augustini et ${ }^{262}$ Parisis 1634. \\
\hline 358. & De vita et moribus sacerdotum Parisis $1550^{263}$. \\
\hline 359. & Libellus sodalitatis - Fran. Costeri. Col. $1589^{264}$. \\
\hline 360. & Exercitia spiritualia. \\
\hline 361. & Meditationes omnes - Manuskrypt. \\
\hline
\end{tabular}

254 Prawdopodobnie w tytule: Granatensis. Brak takiego wydania, być może fragment dzieła $\mathrm{z}$ innym tytułem i przedmową datowaną Romae 1581 .

255 Estr. XV-XVIII, t. 12, s. 456.

256 EBBE online.

257 Estr. XV-XVIII, t. 17, s. 369.

258 Autor: Bonawentura, św. Estr. XV-XVIII, t. 13, s. 251.

259 Estr. XV-XVIII, t. 15, s. 332.

260 Wydane w Hradec Králové.

261 Ossol. XVI.O.8124. Zob. Knyhozbirnya, s. 39, poz. 12.

262 Zapis niedokończony. W tytule: Meditationes, soliloquia, \& manuale.

263 Ossol. XVI.O.8164-8165. Zob. Knyhozbirnya, s. 40, poz. 17.

264 Ossol. XVI.O.8217. Zob. Knyhozbirnya, s. 41, poz. 21. 
Agnieszka Franczyk-Cegła

\begin{tabular}{|c|c|}
\hline 362. & Norma probationis Apticae ${ }^{265}$. - Jakób Radliński Lublini $1732^{266}$. \\
\hline 363. & Actus interni ${ }^{267}$ variarum virtutum - Vilnae $1741^{268}$. \\
\hline 364. & Meditationes De fidei misteriis ${ }^{269}$ Lud. de Ponte - Coloniae 1613. \\
\hline 365. & De studio perfectionis - Joan. Crombecii Moguntiae [1]614. \\
\hline 366. & Praecationes cathecheses - Mart. Eisengrein. Ingolstadii 1578. \\
\hline 367. & Palestra pietatis - Joan. Morawski - Poznań 1676. \\
\hline 368. & Mowy do duchowieństwa - Massiliona. Warszawa [1]788270. \\
\hline 369. & Przewodnik grzesznikow - Ludw. z Grenady Lublin. [1]687. \\
\hline 370. & Uwagi chrześcijańskie. Brunsberg 1708. \\
\hline 371. & Excitationes animi in Deum. - Joan. Ludovici. Coloniae $1563^{271}$. \\
\hline 372. & Myśli pokutującego - bez tytułu i końca. \\
\hline 373. & Geistliche Stadt Gottes. 3! Thail aus der Spanischen J. Jesu ${ }^{272}$ \\
\hline 374. & Kochanie P. Jezusa. Just. Zaruski. Warszawa $1701^{273}$. \\
\hline 375. & Dokument mitosierdzia Bożego. Wilno $1754^{274}$. \\
\hline 376. & Manna duszy - Paweł Segner. - Sandomierz 1730 Część 4ta ${ }^{275}$. \\
\hline
\end{tabular}

265 Apostolicae.

266 Estr. XV-XVIII, t. 26, s. 34.

267 I. e. internos.

268 Autor : Sebastian Bolski. Część druga dzieła Exemplar vitae spiritualis et perfectionis pt. Pars secunda actus internos variarum virtutum complectitur. Estr. XV-XVIII, t. 13, s. 245.

269 Początkowo mysteriis, po czym przekreślono „y” poprawiając na „i”.

270 Prawdopodobnie Mowy Xiędza M. Massiliona Biskupa de Ciermont, na konferencyach duchownych y synodach dyecezalnych miane o szczególnieyszych obowiąkach stanu duchownego z francuskiego na oyczysty język przełożone przez X. Józefa Łopacińskiego koadiutora scholastyka katedralnego wileńskiego, kanonika zmudzkiego.

271 Wydanie niezidentyfikowane; prawdopodobnie błąd w zapisie daty - tytuł wyszedł w 1562; jego egzemplarz z kolekcji sąsiadowickiej znajduje się w Ossolineum: Ossol. XVI.O.8045. Zob. Knyhozbirnya, s. 56-57, poz. 79.

272 Jedno z wydań (być może z 1716 r.) Geistliche Stadt Gottes aut. María de Jesús de Ágreda.

273 Autor: Antoni Krzesimowski. Bernard Justynian Zaruski był tłumaczem. Estr. XV-XVIII, t. 20 , s. 323 ; t. $34 /$ II, s. 402 .

274 Estr. XV-XVIII, t. 28, s. 33.

275 Estreicher notuje jedynie część 4 z 1739 r. Zob. XV-XVIII, t. 27, s. 345-346. 
Księgozbiór karmelitów dawnej obserwancji w Sąsiadowicach

\begin{tabular}{|c|c|}
\hline 377. & Meditationes historicae - Phil. Camerarii. Frankfurti. \\
\hline 378. & Mater amoris et doloris - Ant. Gunther 1734. \\
\hline 379. & Pustynia Bogumyślna. - Jan Morawski - Poznań $1699^{276}$. \\
\hline 380. & Praxis orationis mentalis - Joan. de Carthg. Venetiis 1618. \\
\hline 381. & Magni hujus seculi exempla $1496^{277}$. \\
\hline 382. & Abhandlungen von evang. Rathen Augsburg $1805^{278}$. \\
\hline 383. & Meditationes variae - (bez tytułu i końca). \\
\hline 384. & Pamiątki pasterskiego Afektu - Józef Masi - Warszawa 1699. \\
\hline 385. & Traktaty ascetyczne - Franc. Aries ${ }^{279}$. \\
\hline 386. & Exercitia compendiosa. - (bez tytułu). \\
\hline 387. & Miasto Swięte - Piotr Kwiatkowski - Lublin $1732^{280}$. \\
\hline 388. & Mons Calvariae - Ant de Guevara Col 1607. \\
\hline 389. & Motiva abstinenda a peccato281 - Nicol. Lancicii - Leopoli $1746^{282}$ \\
\hline 390. & Calendarium B. V. Mariae - Ant de Belinghem ${ }^{283}$ - Duacii 1633. \\
\hline 391. & Missaele fr. Praedicatorum. \\
\hline 392. & Die grosse Postille - Jacobi Feuch Eppi - Köln 1578. \\
\hline 393. & Kazania niedzielne (bez początku i końca). \\
\hline 394. & „, ,, tom 2gi Ant. Węgrzynowicz Warszawa $1714^{284}$. \\
\hline
\end{tabular}

276 I.e. Ambona Ducha swiętego do Serca mowiacego, Bogomyslna Pustynia. Bibliografie (Estreicher XV-XVIII, 22, 552, Sommervogel. - 1836, 3, 506, 18) notują jedynie wydanie z 1700 r.).

277 Wydanie niezidentyfikowane.

278 I.e. Das ächte Christenthum in katechetischen Sonntagspredigten : Eine Erläuterung des berühmten Normalkatechismus K. K. Staaten. 3,4, Von den guten Werken und evangelischen Räthen.

279 Być może chodzi o dzieła hiszpańskiego teologa Francisco Rojas Borja y Aries.

280 Autorka: Maria z Agredy. Piotr Kwiatkowski był tłumaczem. Estr. XV-XVIII, t. 12, s. 74.

281 I.e. Motiva abstinendi a peccatis mortalibus.

282 Estr. XV-XVIII, t. 21, s. 42.

283 I.e. Ephemeris seu kalendarium SS. Virginis genitricis Dei Mariae aut. Antoine de Baunghem.

284 Estr. XV-XVIII, t. 32, s. 308-309. 
Agnieszka Franczyk-Cegła

\begin{tabular}{|c|c|}
\hline 395. & Kazania na uroczystość N. P. M. Jan Damascen Warszawa $1726^{285}$. \\
\hline 396. & Kazania niedzielne - Idzi od S. Józefa Kraków $1741^{286}$. \\
\hline 397. & Kazania rozmaite - Rozmaitych Kaznodziejów. \\
\hline 398. & „, niedzielne i pogrzebowe - Alex Lorencowicz - Kalisz 16712 tomy ${ }^{287}$. \\
\hline 399. & Adwent $z$ Postem - Samuel Wysocki - Warszawa $1760^{288}$. \\
\hline 400. & Miscelanea oratorskie - Jan Ostrowski - Lublin $1745^{289}$. \\
\hline 401. & Kazania niedzielne - Ant. Siarkowicz - Lwów $1718^{290}$. \\
\hline 402. & , ,, Ber. Gutowski - Warsz. $1696^{291}$. \\
\hline 403. & ,o niepok. poczęciu-Mik. Kurdanowski - Lwów $1718^{292}$. \\
\hline 404. & , niedzielne - lit. got. Bez tytułu. \\
\hline 405. & , , , , Szym. Starowolski ${ }^{293}$. \\
\hline 406. & Dzieło zbawienia - Ant. Stefanowicz - Kraków $1678^{294}$. \\
\hline 407. & Kazania niedzielne - Fab. Birkowski ${ }^{295}$ \\
\hline 408. & Kazania ks. Piotra Skargi - Kraków $1607^{296}$. \\
\hline
\end{tabular}

285 Właściwie: Korona z prześwietnych dostoyności z cnot nieskończoney godności y lask nieprzebraney hoyności Krolowey Nieba y Ziemie Nayświętszey Boga Matce Pannie Maryi uwita. Autor: Jan Damascen Kaliński. Estr. XV-XVIII, t. 19, s. 58.

286 Właściwie: Rok kaznodzieyski albo kazania na niedzielę. Estr. XV-XVIII, t. 22, s. 27.

287 Estr. XV-XVIII, t. 21, s. 408-409.

288 Estr. XV-XVIII, t. 33, s. 463.

289 Właściwie: Swada polska y łacińska, albo miscellanea oratorskie. Estr. XV-XVIII, t. 23, s. 517.

290 Właściwie: Miecz sprawiedliwości. Estr. XV-XVIII, t. 28, s. 5.

291 Estr. XV-XVIII, t. 17, s. 477.

292 I.e. Kurdwanowski, który nie był autorem, lecz nakładcą. Autorem druku był nieznany z nazwiska ówczesny proboszcz kościoła tomaszewskiego, w którym wygłoszono kazanie. Zob. Estr. XV-XVIII, t. 19, s. 201.

293 Właściwie: Arka Testamentu, zamykaiaca w sobie kazania niedzielne catego roku wydana w Krakowie w 1648 r. Estr. XV-XVIII, t. 29, s. 187-188.

294 Estr. XV-XVIII, t. 29, s. 270.

295 Jedno z trzech wydań krakowskich z 1620, 1623 i 1628 r. Estr. XV-XVIII, t. 13, s. 142-143.

296 Estreicher nie notuje wydania $\mathrm{z}$ tą data. Zob. Estr. XV-XVIII, t. 142-149. 
Księgozbiór karmelitów dawnej obserwancji w Sąsiadowicach

\begin{tabular}{|c|c|}
\hline 409. & Kazania niedz. Krasnowskiego ${ }^{297}$. \\
\hline 410. & Comment. i[n] Marcum et Lucam - Joh. Hofmeister Lovanii 1562. \\
\hline 411. & Mariale - Ber. de Busti - Argentinae $1496^{298}$. \\
\hline 412. & Homiliae - Frid. Blanciampi - Coloniae $1530^{299}$. \\
\hline 413. & Regolamenta del Regio Arcispedale - Firenze 1783. \\
\hline 414. & Kazania świąteczne - Starowolski. (bez początku) ${ }^{300}$. \\
\hline 415. & Leben Karls des III v Spanien Leipzig 1708. \\
\hline 416. & Epitome historiarum - Joach. Vadiani. \\
\hline 417. & Res gesta i[n] Hispania - Jansoni Frisio - Colon. Agrip. 1598. \\
\hline 418. & Ex Trogo Pompejo historia - Justini - Frankfurti 1617 - 2 tomy. \\
\hline 419. & Historiae profanae - Pauli Jovii - Basilae 1560 - 2 tomy. \\
\hline 420. & Fax chronologica - Joan. Musantii Sandomiriae $1724^{301}$. \\
\hline 421. & Dzieje rzeczy po Rzymsk. Albertrandy. Warszawa $1768^{302}$. \\
\hline 422. & Historia ecclesiastica - Laur. Moshenni - Helmstadii $1764-2$ tom. \\
\hline 423. & Historia ecles. collquis digesta - Ign. de Graveson - Venetiae 1738. \\
\hline 424. & Dzieje Królestwa polskiego - Jan Albertrandy - Lwów $1846^{303}$. \\
\hline 425. & Geschichte des Reiches Gottes - Jos. Wittman Linz 1830. 9 tomów. \\
\hline 426. & Historia ecles. - Xav. Gmeiner - Gracii 18032 tomy. \\
\hline
\end{tabular}

297 Najprawdopodobniej Chwała świętych bożych na kazaniach całego roku Jana Krosnowskiego (wydane dwukrotnie: w Poznaniu 1691 r. oraz w Kaliszu w 1704 r.) lub Pochodnia stowa Bożego w kazaniach niedzielnych wydane w Lublinie w 1689 r. Estr. XV-XVIII, t. 20, s. 289-290.

298 IBP 1345. ISTC ib01334000. Obecnie Ossol. XV.305. Zob. Knyhozbirnya, s. 37, poz. 7.

299 Nauseae Fredericus Blancus Campani, Tres Evangeliae veritatis homiliarium centuriae, [Köln : Petrus Quentell], 1530. Egzemplarz BKKr, sygn. XVI. 378.

300 Najprawdopodobniej jedno z dwóch wydań zbioru kazań na święta całego roku pt. Świątnicy pańskiej z 1645 lub 1682 r.; ewentualnie Wieniec niewiędniejący zwierający kazania na święta maryjne. Zob. Estr. XV-XVIII, t. 29, s. 210211.

301 Estr. XV-XVIII, t. 22, s. 639.

302 Autor: Philippe Macquer. Jan Albertrandi był thumaczem. Estr. XV-XVIII, t. 22, s. 17.

303 Autor: Fryderyk August Schmidt. Jan Albertrandi był thumaczem. Estr. XIX, t. 4, s. 197. 
Agnieszka Franczyk-Cegła

\begin{tabular}{|c|c|}
\hline 427. & Dzieje polityczne Europy, tom 5ty - Ign. Chodyniecki Lwów $1819^{304}$. \\
\hline 428. & Sex historiae augustae - Marc. Boxhorn - Lugd. Bat. 1631. \\
\hline 429. & Memoria hist. conc. general. - Joan. Baduarii - Venet. [1]689. \\
\hline 430. & Historiae Polonae - Pars I. - Joach. Pastorii - Gedani $1680^{305}$. \\
\hline 431. & Historia poetica - Paulus gautruche - Tyrnaviae 1728. \\
\hline 432. & Allgemeinen Geschichte der neuern Zeit - Regensburg 18413 tomy. \\
\hline 433. & Iuris prudentiae ecclesiasticae ${ }^{306}$ - Pauli Rieger Vindobonae 1771.4 tomy. \\
\hline 434. & Codex civilis austr. ${ }^{307}$ - Viennae 1781. \\
\hline 435. & Ius ecclesiast. universum. tom I. Jos. Pehem - Viennae 1791. \\
\hline 436. & Procesus judiciarius - Jac. Janidlovio Bozantino. Cracoviae $1606^{308}$. \\
\hline 437. & Enchiridion juris eclestici. - Georg Rechberg - Lincii 1809. \\
\hline 438. & Codex civilis pro Galicia orient. Viennae 1797. \\
\hline 439. & Insitutiones juris ecles. - Xav. Gmeineri Gracii 1808. \\
\hline 440. & Elementa juris pontifici - Ant. Hochkirchen Brunae $[1] 729^{309}$. \\
\hline 441. & Suprema R[o]m[an]ae Pontificis auctoritas ${ }^{310}$ And. Narolski Przemysl $1759^{311}$ \\
\hline 442. & Processus judiciaries - Joan. Pelsii Coloniae 1614. \\
\hline 443. & De judiciis - Ant. Mathei. \\
\hline 444. & Systema corporis juris - Joach. Schöpfer Lipsiae 1717. \\
\hline
\end{tabular}

304 Estr. XIX, t. 1, s. 196.

305 Estr. XV-XVIII, t. 24, s. 113-114.

306 I.e. Institutionum iurisprudentiae ecclesiasticae principia.

307 I.e. Codex civilis iudiciarius communis omnibus iudicibus constitutis in Bohemia, Moravia, Silesia, Austria superiori, ac inferiori, Stiria, Carinthia, Carniola, Goritia, Gardisca, Tergesto, Tyroli, atque Austria anteriore.

308 Estr. XV-XVIII, t. 18, s. 450

309 Wydanie niezidentyfikowane.

310 I.e. De suprema Romani Pontificis auctoritate.

311 Estr. XV-XVIII, t. 23, s. 291. 
Księgozbiór karmelitów dawnej obserwancji w Sąsiadowicach

\begin{tabular}{|c|c|}
\hline 445. & Regulae juris. - Stanis Lochowski - Cracoviae $1637^{312}$. \\
\hline 446. & Juris prudentia germanica - Georg. Struvii Jenae 1768. \\
\hline 447. & Rekolekcye - Marcin Rubczyński Berdyczów $1762^{313}$. \\
\hline 448. & Martyrologium romanum. Romae 1723. \\
\hline 449. & Rozmowy z prawa kanonicznego - Tym. Szczurowski $1792^{314}$. \\
\hline 450. & Ceremoniale ordinis. B.M. V. de monte Carmel ${ }^{315}$. \\
\hline 451. & Italienische und franz. Gram. - Jos. Meidinger - Frankfurt $1803^{316}$ \\
\hline 452. & Philothea - 6 Jahrgange - Würzburg 1840. \\
\hline 453. & Szkótka Niedzielna - roczników 3. Leszno $1837^{317}$. \\
\hline 454. & Fragmenta Eplar. ${ }^{318}$ S. Francisci Xaverii. Calisii $1716^{319}$. \\
\hline 455. & Insitutiones pol relig ${ }^{320}$ - Stanis. Kleczowski ${ }^{321}$ - Leopoli $1758^{322}$. \\
\hline 456. & O zyciu i pismach Voltera - p. Akad. Kraków Warszawa $1781^{323}$. \\
\hline 457. & Kancyonat pruski - gotyckim drukiem, b. dawny ${ }^{324}$. \\
\hline
\end{tabular}

312 Estr. XV-XVIII, t. 21, s. 371.

313 I.e. Glos pana kruszacego cedry libańskie albo rekollekcye. Estr. XV-XVIII, t. 26, s. 436.

314 Estr. XV-XVIII, t. 30, s. 229-230.

315 Np. Ceremoniale divini officii, secundum Ordinem Fratrum B. Virginis Mariae de Monte Carmeli : ad normam novi missalis \& breviarii compilatum..., Romae : apud Guilielmum Faciottum, 1616.

316 I. e. Praktische italienische Grammatik wodurch man diese Sprache auf eine ganz neue und sehr leichte Art in kurzer Zeit gründlich erlernen kann.

317 Czasopismo. Estr. XIX, t. 1, s. 262.

318 Epistolarum.

319 Autor: Jan Kuszewicz. Estr. XV-XVIII, t. 20, s. 408.

320 I.e. politico-religiosae.

321 I.e. Kleczewski.

322 Estr. XV-XVIII, t. 19, s. 274.

323 Autor: Johann Christoph von Zabuesnig. Estr. XV-XVIII, 31, 377.

324 W XVIII w. wyszedł Kancyonat pruski wydany przez D. Rogalliego w Królewcu w 1731 r. Jak pisze Estreicher: „Rogalli był tylko wydawcą tego Kancyonału (opartego oczywiście na starszych Kancyonałach pruskich). Wyszedł on w ciągu w. XVIII podobno w kilkudziesięciu edycyach”. Ponieważ inwentaryzujący nie odnotowuje dodatkowych informacji dotyczących wydania, należy przypuszczać, że w bibliotece sąsiadowickiej znajdował się defekt. Nie wiadomo, czy tytuł w inwentarzu „Kancyonał pruski” to tytuł rzeczywisty (np. z żywej paginy - wtedy nie chodziłoby o wspomniane wydanie z 1731 r., gdyż tam takowy nie występuje), czy też jest to tyuł sztuczny, a chodzi 
Agnieszka Franczyk-Cegła

\begin{tabular}{|c|c|}
\hline 458. & Aurea mensis symbola - Melch. Cibinensis Ungar. ${ }^{325}$. \\
\hline 459. & Constitutiones Ordinis Nostri - Romae 1625. \\
\hline 460. & Panoplia exegetica - Maximi Raslii. Vindel 1740. \\
\hline 461. & Theologia Dogm. Moralia - tom 1szy Danieli Concineae - Bononiae 1769. \\
\hline 462. & Vita S. Guntheri, Bernard. Brunae 1762. \\
\hline 463. & Żywot s. Kajetana. - Anioł Ostroróg karm. Kraków $1719^{326}$. \\
\hline 464. & Geschichte und Schriften der Apostel Jesu, Zürich 1775. \\
\hline 465. & Kazanie w czasie koronacyi N.M.P. Sokalskiej-1724 327. \\
\hline 466. & Considerationes in Psal. Cant. - Jacobi Radlinski - Lublini $1734^{328}$. \\
\hline 467. & Epistolae Ant. Mureti - Col. Agrip. 1580. \\
\hline 468. & Józef we śnie - Jan Heume - Kraków $1801^{329}$. \\
\hline 469. & O powrocie Jezuitów - z francuzkiego - Warszawa 1805 - 2 tom $^{330}$. \\
\hline 470. & Osobliwości Włoch - bez tytułu ${ }^{331}$. \\
\hline 471. & O władzy duchownej - Warszawa $1820^{332}$. \\
\hline
\end{tabular}

np. o jedno z wydań kancjonału toruńskiego z XVI w. - wtedy zasadna byłaby uwaga inwentaryzującego „b. dawny”, która z pewnością nie byłaby zastosowana przy wydaniach XVIII-wiecznych. Zob. EBBE online s.v. Cantional, Kancyonat itp.

325 Prawdopodobnie fragment Symbola Aureae Mensae aut. M. Maiera (Frankfurt, 1617), gdzie włączono jako rozdz. 11 alchemiczna parafrazę mszy św. aut. Melchiora Cibinensis (z przydomkiem Ungarus) Processus sub forma missae.

326 I.e. Ogród liliowy y cedrowy ... albo zywot S. Kajetana. Estr. XV-XVIII, t. 23, s. 506.

327 W tym roku o tejtematyce wyszło w Zamościu Wieczność nieustaiacey pamiątki w koronach złotych nayprzecudnieyszego obrazu Nayświętszey Maryi Panny przy solenney jego od wieków pożadaney koronacyi w Sokalskiey bazylice Ignacego Orłowskiego. Zob. Estr. XV-XVIII, t. 23, s. 428-429.

328 Właściwie: Sepultura viventium in sepulchro Christi seu considerationes in Psalmos. Estr. XV-XVIII, t. 26, s. 35.

329 Estr. XIX, t. 2, s. 126.

330 Autor: Adam Łabęcki. Estr. XV-XVIII, t. 3, s. 1.

331 Najprawdopodobniej Cuda i osobliwości natury i sztuki w różnych znayduiace się kraiach : z naynowszych i nayciekawszych podróży do wszystkich części świata zebrane Ambrożego Grabowskiego, gdzie w tomie 1. występuje tytuł nagłówkowy na s. 1.: „Osobliwości Włoch”. Wydania: Kraków 1811, Berdyczów 1819, Kraków 1811. Estr. XIX, t. 2, s. 71.

332 Autor: Wojciech Skarszewski. Estr. XIX, t. 4, s. 255. 
Księgozbiór karmelitów dawnej obserwancji w Sąsiadowicach

\begin{tabular}{|c|c|}
\hline 472. & Dobry pasterz - Łowicz $1780^{333}$. \\
\hline 473. & Memoranda regni Poloniae - Manuskrypt. \\
\hline 474. & Memoria artificialis - Coloniae 1617. \\
\hline 475. & Sulpitii Severi historiae sacrae - Col. Agrip. 1573. \\
\hline 476. & Atlas in 26 Karten - Nürnberg. \\
\hline 477. & Com [m]entaria in omnes libros S. Scripturae Corneli a Lapide - 9 tomów ${ }^{334}$. \\
\hline 478. & Opera S. Bernardi Parisiis 1602. \\
\hline 479. & Epitome oper: S. Augustini $i^{335}$. \\
\hline 480. & Explanationes S. Ambrosii (bez tytułu i końca). \\
\hline 481. & Tertulianus praedicans - Mich. Viviem - Pat: $1747^{336}$. \\
\hline 482. & Opera Basilii Magni. Basileae 1552. \\
\hline 483. & Opera S. Joannis Chrysostomi - ultimus tomus Basileae $1530^{337}$. \\
\hline 484. & Bibliotheca patrum Auct. - Parisiis $1610^{338}$. \\
\hline 487 [!]. & Conciones Evangeliorum - Corn. Mussi ${ }^{339}$. \\
\hline 488. & Homiliae in E[van]g[e]lia - Corn. Janson - Col. $1570^{340}$. \\
\hline 489. & Tesaurus laudum B.V.M. - Abrah. Bsovi Venet $1597^{341}$. \\
\hline 490. & Promptuarium catholicum. Tom. Stapleton Col. Agrip. CIDIDXCIII - 2 tomy $y^{342}$ \\
\hline
\end{tabular}

333 Estr. XV-XVIII, t. 24, s. 108.

334 Tytuł najprawdopodobniej sztuczny. Być może wydanie z 1693-1703.

335 Wydanie niezidentyfikowane, tytuł wyszedł w roku 1537, 1542, 1555

336 I.e. Patavii.

337 I.e. Ultimus tomus operum divi Ioannis Chrysostomi..., Basileae: Ex officina Frobeniana, 1530. Egzemplarz BKKr, sygn. XVI.144. Na oprawie superekslibris Piotra Kmity z herbem Szreniawa.

338 I.e. jeden z tomów dzieła Bibliotheca veterum patrum et auctorum ecclesiasticorum ... / per Margarinum De La Bigne.

339 Wydanie kolońskie z 1603 r. Ossol. XVII-13.102. Zob. Knyhozbirnya, s. 49, poz. 48.

340 Ossol. XVI.O.8901. Zob. Knyhozbirnya, s. 46, poz. 39.

341 Bibliografie notują weneckie wydanie Thesaurusa Abrahama Bzowskiego jedynie z $1598 \mathrm{r}$. Być może jest pomyłka inwentaryzującego.

342 Ossol. XVI.O.9585. Posiadali też wydanie z roku 1594: Ossol. XVI.O.9397-8, XVI.O.9425. 
Agnieszka Franczyk-Cegła

\begin{tabular}{|c|c|}
\hline 491. & Conciones quadragesimales diversae (bez tytułu i końca). \\
\hline 492. & Conciones festivales diversae. \\
\hline 493. & Enarrationum E[van]g[e]liarum - Hier. de Marnef Parisiis $1574^{343}$. \\
\hline 494. & Promptuarium morale - Laur. Beyerlinck Col. Agrip. 1618 - 4 tomy ${ }^{344}$. \\
\hline 495. & Sermones funebrales - Georg a Breitenberg - Col. Agrip. $1611^{345}$. \\
\hline 496. & Sermones de tempore - (bez tytułu i końca). \\
\hline 497. & Panegyrici sacri - Paul Segneri - Vindel. 1750. \\
\hline 498. & Conciones quotid. quadrages. - Philippi Diez Lugduni 1586. \\
\hline 499. & Conc. de missae sacrificio - Mich. Eppus - Col. $1549^{346}$. \\
\hline 500. & Bibliotheca concionatoria - Const. Letins - Colon. Agrip. $1740^{347}$. \\
\hline 501. & Rosarium aureum - Guil. Pepin - Venetiis - $1592-2$ tomy $^{348}$. \\
\hline 502. & Conciones festivae - Lud Pranatensis ${ }^{349}$ - Antverp. 1588. \\
\hline 503. & Conciones annuae et festivae - Jak. Schoepper Fremaniae 1566 - 2 tomy. \\
\hline 504. & Exempla S. Scripturae - Petri Canisi Colon. 1570. \\
\hline 505. & Auctoritas,,,${ }^{350}$. \\
\hline 506. & Commentaria in epist: Pauli - Basileae $1552^{351}$. \\
\hline
\end{tabular}

Zob. Knyhozbirnya, s. $54-55$, poz. 72 ; s. 55 , poz. $73,75,74$.

343 Hieronymus de Marnef był drukarzem. Autorem dzieła był Petrus de Palude. Ossol. XVI.O.9108-9. Zob. Knyhozbirnya, s. 51, poz. 57.

344 Najprawdopodobniej egzemplarz Lwowskiej Narodowej Naukowej Biblioteki Ukrainy im. W. Stefanyka (dalej: LNNBU), sygn. CT-101256. Wydanie z 1617 r., w inwentarzu błędny zapis. Zob. Knyhozbirnya, s. 38, poz. 10.

345 I.e. Pontanus von Breitenberg, Georg Barthold. Najprawdopodoniej LNNBU, sygn. CT101601. Zob. Knyhozbirnya, s. 52, poz. 62.

346 Ossol. XVI.Qu.11911.

347 I.e. Theologia concionatoria.

348 Ossol. XVI.O.8909. Zob. Knyhozbirnya, s. 50, poz. 55.

349 I.e. Granatensis.

350 Najprawdopodobniej w poz. 504 i 505 chodzi o cz. 3 i 4 wydania Authoritatum Sacrae scripturae et sanctorum patrvm quae in Catechismo Doctoris Petri Canisii citantur P. Busaeusa drukowanego w Kolonii przez dziedziców J. Quentela w $1570 \mathrm{r}$.

351 Ossol. XVI.O.8993. Zob. Knyhozbirnya, s. 49, poz. 49. 
Księgozbiór karmelitów dawnej obserwancji w Sąsiadowicach

\begin{tabular}{|c|c|}
\hline 507. & Conceptuum aparatus - Franc. Garau - Ingolstadi ${ }^{352}$. \\
\hline 508. & Hortulus Reginae - Meffreti - Venet. 1612. \\
\hline 509. & Locorum com [m] unium summa - Phil. Diei - Venet. $1595^{353}$. \\
\hline 510. & Homiliae Vener. Bedae Presbyterii Col $1535^{354}$. \\
\hline 511. & Conciones Dominicales - Samuelis Loyaerts - Col. Agp. 1691. \\
\hline $212[!]$ & Sermones de Sanctis - Rud. Clitii ${ }^{355}$ - Col. 1626. \\
\hline 513. & Paslilia $^{356}$ - Gasp. Hochfedor - bez początku i końca) ${ }^{357}$. \\
\hline 514. & Flosculi S. Scrip: et conc. - (bez tytułu). \\
\hline 515. & Homiliae in Ep[isto]las et E[van]g[e]liae - Rud. Ardentis - Col. 1604. \\
\hline 516. & Sermones quadrag: - Guil. Pepin Venet : $1591^{358}$. \\
\hline 517. & Sermones morales - Joan. Guinlini ${ }^{359}$ - Col. 1608. \\
\hline 518. & Homiliae annuae - Haymonis Ep[isco]pi - Col: 1539 - 2 tomy $^{360}$. \\
\hline 519. & Conciones D[omi]ni]cales et fest: - Pil. Busei - Col : Agrip. 1573 - 2 tom. \\
\hline 520. & Ennarationes in E[van]g[e]lia - Fran. Polygrani - Col: 15602 tomy $^{361}$. \\
\hline 521. & Homiliae de Sanctis - Henr. Helmesi - Paris 1553. \\
\hline 522. & Conciones super Ps. poenit: - (bez początku). \\
\hline 523. & Commentationes in Adventum - Fried. Bartscii Cracoviae $1585^{362}$. \\
\hline
\end{tabular}

352 Być może wydanie z 1731 lub 1732. Bibliografie nie notują wcześniejszej edycji tego tytułu; Sommervogel w ogólne go nie odnotowuje.

353 I.e. Summa praedicantium, ex omnibus locis communibus locupleti $\beta$.

354 Ossol. XVI.O.9488. Zob. Knyhozbirnya, s. 37, poz. 6.

355 I.e. Clutii.

356 I.e. Postilla.

357 Być może: Guillermus Parisiensis, Postilla super epistolas et evangelia, Nuremberg : Caspar Hochfeder, 25 III 1496. IBP 2659. ISTC ig00700000.

358 Ossol. XVI.O.9021. Zob. Knyhozbirnya, s. 50, poz. 54.

359 I.e. Quintini.

360 Pars hiberna: Ossol. XVI.O.8317. Pars aestivalis: XVI.O.9589 (wydana w 1540). Zob. Knyhozbirnya, s. 44, poz. 30; s. 44, poz. 31.

361 Ossol. XVI.O.8874/1; XVI.O.9033. Zob. Knyhozbirnya, s. 51, poz. 60; s. 52, poz. 61.

362 Estreicher notuje jedynie wydanie z 1607 r. pod tytułem: In Evangelia adventus et quae 
Agnieszka Franczyk-Cegła

\begin{tabular}{|c|c|}
\hline 524. & Conciones variae - Joan Osorii - Venet 1595 - 2 tomy. \\
\hline 525. & Sermones aurei - Gab. Barleti - Ven. 1585. \\
\hline 526. & Sermones de Sanctis - Rud[olph]i Clautii ${ }^{363}$ - Col 1612. \\
\hline 527. & Sermones dominicales - (bez początku i końca). \\
\hline 528. & Sermones quadrages: - Didaci de la Vega - Col $1608^{364}$. \\
\hline 529. & Ennarationes E[van]g[e]l[i]orum - Henr Luytenii - Antverpiae $1565^{365}$ \\
\hline 530. & Diurnale concionator - Rud. a Tosignano - Col. $1530^{366}$. \\
\hline 531. & Dictionarium concionat,$"$ \\
\hline 532. & Sermones feriales - Venet 1516. \\
\hline 533. & Aureum Diurnale - Barth a Breitenberg - Col. Agrip. $1620^{367}$. \\
\hline 534. & Concordia Evangeliorum - Joan. Buisonei [?] (bez tytułu). \\
\hline 535. & Homiliae domin. - Joan. Hofmeister - Ingolst. $1549^{368}$. \\
\hline 536. & , in mysterio Dom [i]ni - Thom. Beauxamis - Antverpiae $1573^{369}$. \\
\hline 537. & Homiliae in G[e]n[esi]m: - Petri Camusii - Parisiis 1616. \\
\hline 538. & Compendium in dominicas - Fried. Blanciampii - Coloniae 1566. \\
\hline 539. & Conc: vesp: quadr: - Did. de la Vega - Col. 16102 tomy. \\
\hline 540. & Conciones variae - Ant. Dulken: Col. 1613 - 2 tomy. \\
\hline 541. & Homiliae dom: Joan Royardii Ant. $1538-2$ tomy $^{370}$. \\
\hline
\end{tabular}

seqquntur dominicarum commentationes. Estr. XV-XVIII, t. 2, s. 396.

363 I.e. Clutii.

364 Por. LNNBU, sygn. CT-101303/2. Zob. Knyhozbirnya, s. 56, poz. 79.

365 Ossol. XVI.O.9212-14. Zob. Knyhozbirnya, s. 48, poz. 45; s. 47, poz. 44.

366 Błędna data - autor, Pietro Ridolfi, żył w 1. 1536-1601. Nieznane jest także wydanie pod tytułem Diurnale concionatorum; notowane przez bibliografie Dictionarium concionatorum (zob. poz. 531) wyszło kilkakrotnie na przełomie XVI/XVII w.

367 LNNBU, sygn. CT-101595. Zob. Knyhozbirnya, s. 52, poz. 63.

368 Ossol. XVI.O.9253. Zob. Knyhozbirnya, s. 45, poz. 33.

369 Ossol. XVI.O.9348. Zob. Knyhozbirnya, s. 37, poz. 5.

370 Ossol. XVI.O.8325-6. Zob. też Ossol. XVI.O.9423: Royaert, Jan: Homiliae in Euangelia Dominicalia iuxta literam, Antverpiae : in aedibus Ioannis Steelsii, 1550. Zob. Knyhozbirnya, s. 53, 
Księgozbiór karmelitów dawnej obserwancji w Sąsiadowicach

\begin{tabular}{|c|c|}
\hline 542. & Concionum 371 apparatus - Fran: Labata - Col. 1615. \\
\hline 543. & Homiliae de Sanctis - Joan. de Chartay: Col: Agrip 1615 - 2 tom. \\
\hline 544. & Concion: ab Adven: usq ad Pascha - Alphonsi Avilae - Antverp 1610. \\
\hline 545. & Conciones de morte - Mas. Sandaei - Moguntiae 1624. \\
\hline 546. & Aurea rosa - Silv de Prierio - Venet: $1549^{372}$. \\
\hline 547. & Sermones dominicales - Pomerii ${ }^{373}$. \\
\hline 548. & „ab Adv: usq. ad Resurect: - Jon Ozorii Venet: $15966^{374}$. \\
\hline 549. & Homiliae totius anni - bez tytułu. \\
\hline 550. & Conciones quadrages: - Ant. Kerbeckii - Romae $1577^{375}$. \\
\hline 551. & Promptuarium morale - Thom. Stapletonii Col. Agrip. 1588. \\
\hline 552. & Homiliae variae - bez tytułu. \\
\hline 553. & Sermones spirituales - Jac. de Grafiis - Venet: $1596^{376}$. \\
\hline 554. & Ennarat: Ev[an]g[e]lio: - Hier. de Marnef - Parisiis 1574. \\
\hline 555. & Fascilulus moralitatis - Joan: And: Koppenstein - Col: Agrip 1615. \\
\hline 556. & Homiliae domini ( - bez tytułu). \\
\hline 557. & „, quadragesim: - Pet. Camusii-Col 1621. \\
\hline 558. & Exilium generis humani - Nicol: Orani - Monti1 ${ }^{377}$ : 1613. \\
\hline
\end{tabular}

poz. 56; s. 53-54, poz. 68 .

371 I.e. Concionatorum.

372 I.e. 1569. Ossol. XVI.Qu.11577. Zob. Knyhozbirnya, s. 48, poz. 46.

373 Chodzi o wydanie kazań Pelbartusa de Themeswar. Być może było to wydanie z 1516 r. bez wyrażonego na karcie tytułowej adresu wydawniczego i daty wydania.

374 Ossol. XVI.Qu.11607 (t. 5 wydany w 1595 r.: Tomus quintus concionum a Dominica prima Adventus, usque ad Pascha Resurrectionis, cum omnibus ferijs quadragesimalibus); z kolekcji sąsiadowickiej w Ossolineum znajduje się także tom 1 oraz 2 kazań Osoriusa wydany w Wenecji w 1596 r. pt. Tomus primus[-secundus] concionum, zob. Ossol. XVI.O.9162. Zob. Knyhozbirnya, s. $49-50$, poz. 52 .

375 Wydanie niezidentyfikowane.

376 Ossol. XVI.Qu.11583. Zob. Knyhozbirnya, s. 43, poz. 27.

377 I.e. Monitb. $=$ Montibus, i.e. Monachium. 
Agnieszka Franczyk-Cegła

\begin{tabular}{|c|c|}
\hline 559. & Conciones de tempore. - Lud: Granatensis - Antverp $1584^{378}$. \\
\hline 560. & Homiliae in Ep[isto]l[a]s et E[van]g[e]lia. - Rud. Ardentis - Antverp: $1570^{379}$. \\
\hline 561. & Homiliae domin. - Ratisbonae 1546. \\
\hline 562. & Conciones ad diversos hominum status Henr: Culens Antverp: 1620. \\
\hline 563. & Varia Antidota - Pauli Vvan - Moguntiae 1615. \\
\hline 564. & Concione [s] dom: et fest: - Mat. Fabii - Colon Agrip. 1642 - 2 tom. \\
\hline 565. & Conc: dom: Philippi a S. Jacobo - Norimbergae 1726. \\
\hline 566. & Sermones Discipuli de tempore et Sanctis Moguntiae 1612. \\
\hline 567. & Sermones $d[e]$ laudibus Sanctorum Rob. de Lizio ${ }^{380}$. \\
\hline 568. & Tractatus evangelici. - Hier de la Nura ${ }^{381}$ Col: Agrip 1617. \\
\hline 569. & Annus apostolicus - Zach. Laselve - Col 1748. \\
\hline 570. & Dicenda concionatoria - Angeli Ostrorog - Leop. $1721^{382}$. \\
\hline 571. & Galea salutis - Liborii Schemlinck - Vind 1721. \\
\hline 572. & Triplices in dominicas conc: - Seb. Penzingeri - Nirenbergae [ !] 1726. \\
\hline 573. & Conceptus Theologici - Pet. Bessaei - Agrip: 1630. \\
\hline 574. & Missale Carmelit: circa Annorum 1564. \\
\hline 575. & Quincuplex psalterium - Frankfortii [!] $1508^{383}$. \\
\hline
\end{tabular}

378 Ossol. XVI.O.9400. Zob. Knyhozbirnya, s. 47, poz. 43.

379 Ossol. XVI.O.9004. Zob. Knyhozbirnya, s. 52-53, poz. 64.

380 I.e. Caracciolus. Ossol. XV.143. Zob. Knyhozbirnya, s. 39, poz. 14.

381 I.e. Nuza = Jerónimo Bautista de Lanuza.

382 Wydanie nieznane Estreicherowi, który odnotowuje edycję z 1723 i 1728 r. Być może pomyłka inwentaryzującego per analogiam do poz. 571. Zob. Estr. XV-XVIII, t. 23, s. 505-506.

383 W BBKr znajduje się Quincuplex Psalterium wydany w Paryżu w drukarni H. Estienne w 1509 (sygn. XVI.376), który jest współoprawny z dziełem autorstwa Konrada Wimpina Epithoma problematum et opinionum primi Sententiarum z 1508 (sygn. XVI.377 adl.). To ostatnie nie posiada wymienionego w druku miejsca wydania, lecz w kolofonie pojawia się zwrot: „Repetitum est hoc epitomum in ... fracofordino gymnasio...”, co wyjaśniałoby, skąd katalogujący wziął owo „Frankofortii" pojawiające się w inwentarzu. 
Księgozbiór karmelitów dawnej obserwancji w Sąsiadowicach

\begin{tabular}{|c|c|}
\hline 576. & Sententiarum textus - Pet: Lombardi - Parisiis $1516^{384}$. \\
\hline 577. & Trinum perfectum a Mich. O. S. Aug - Augsb. $1722-3$ tomy. \\
\hline 578. & Sermones dominicales - Dion. Carthusiani Col: Agrip 1537. \\
\hline 579. & „, , et festivi - lit. got. / bez tytułu. \\
\hline 580. & Biblia immaculata - Viti Schefer - Prag: $1711^{385}$. \\
\hline 581. & Sum [m] a confes: - Joan. de Friburgo. - $1517^{386}$. \\
\hline 582. & Sermones domin. et fest. Joan: Feri Moguntiae $1559-3$ tomy ${ }^{387}$. \\
\hline 583. & Teatrum humanae historiae - Teod: Zwinger - A. CIDICLXXI. \\
\hline 584. & Florilegii magni - Lugduni 1548. \\
\hline 585. & Theologia moralis - Mart. Bonacinae Lugduni 1629. \\
\hline 586. & Homiliae dom: - Laur. Lurii ${ }^{388}$ Col Agrip: 1576. \\
\hline 587. & Conciones fest: - (bez tytułu i końca). \\
\hline 588. & Homiliae de tempore - Nausea Friedr. Moguntiae 1538. \\
\hline 589. & Rationale divinorum off[ici]orum Lugd. $1570^{389}$. \\
\hline 590. & Sermones de Balissimo ${ }^{390}$ - Bernd. de Bustis Brixiae $1598^{391}$. \\
\hline 591. & Missale pro itinerantibus - lit: got: Cracoviae $1545^{392}$. \\
\hline
\end{tabular}

384 Por. BKKr, sygn. XVI.361 - wydane w Kolonii w oficynie L. Hornkena w 1516 r., które posiada proweniencję sąsiadowicką (co ciekawe, zostało zakupione przez klasztor w Krakowie).

385 W BKKr znajduje się t. 1, bez sygn.

386 Ioannes de Friburgo, Summa confessorum, Lyon: Jac. Saccon pro I. Koberger, 1518. Egzemplarz BKKr, sygn. XVI. 331. Współoprawne z Thomas de Vio Caietanus, Liber Psalmorum ad verbum ex Hebraeo versorum ... enarratus, [Paris]: J. Badius; J. Petit; J. de Roigny, 1532. Egzemplarz BKKr, sygn. XVI. 332 adl.

387 Ferus Ioannes, Postillae sive concionum pars secunda, Köln: A. Birckmann - Erben, 1559. Egzemplarz BKKr, sygn. XVI.529; toż, sygn. XVI.519, wspóloprawne z Canones Apostolorum, Mainz: J. Schoeffer, 1525, sygn. XVI.520.

388 I.e. Surii.

389 I.e. 1510, wyd.: Lyon, J. Sacon, 1510. Egzemplarz BKKr, sygn. XVI. 354.

390 I.e. Beatissimo.

391 Bernardinus de Bustis, Mariale seu sermones de Beatissima Virgine Maria, t. 3, Brixiae: P.Marchettus, 1588. Egzemplarz BKKr, sygn. XVI. 813.

392 Ossol. XVI.Qu.2884. Zob. Knyhozbirnya, s. 48, poz. 47. 
Agnieszka Franczyk-Cegła

\begin{tabular}{|c|c|}
\hline 592. & „, Romanorum - lit: got: Venet: 1580. \\
\hline 593. & Sum [m] a casuum conscientiae - Thom. Sanchez Colon. Agrip 1614. \\
\hline 594. & Arbor opiniorum moralium - Bononiae $1693^{393}$. \\
\hline 595. & Missale Carmelit: 1611. \\
\hline 596. & Kazania świąteczne - Narolski - (bez tytułu i końca) ${ }^{394}$. \\
\hline 597. & Edicta pro Galicya et Lod: Leopoli $1784^{395}$. \\
\hline 598. & Sermones Annui - Jodoci Clichtov. - (bez tytułu). \\
\hline 599. & Historia monasteri Miechoviae - Samuel Nakielski - Cracoviae [1]634 ${ }^{396}$. \\
\hline 600. & Sermones Domn: - Nicol. de Błonie ${ }^{397}$. \\
\hline 601. & Postile Joanis [!] Feri - Mogunt. 1558 - 2 tomy. \\
\hline 602. & Sermones de Sanctis - (bez tytułu). \\
\hline 603. & Elogia de B.V:M: Ant. de Escobor - Lugd. 1669. \\
\hline 604. & Loci communes - conradii Kling - Colon: 1565. \\
\hline 605. & Conc. dominical: - Stan. Makowski - Cracoviae $1668^{398}$. \\
\hline 606. & Vocabularius - lit: got: - Argentinae $1499^{399}$. \\
\hline 607. & Sylabus Marianus - Ant. Węgrzynowicz - Leop. $1714^{400}$. \\
\hline
\end{tabular}

393 W BKKr, t. 2, brak sygn.

394 Dzieło niezidentyfikowane.

395 I.e. Continuatio edictorum. Estr. XV-XVIII, t. 16, s. 17.

396 Estr. XV-XVIII, t. 23, s. 25-27.

397 Prawdopodobnie chodzi o Sermones de tempore et de sanctis, sive Viridarius, Strasburg : [Typographus Jordani de Quedlinburg (Georg Husner)], 1494-95. IBP 3933. ISTC in00091000. Wydanie posiadało stronę tytułową z wyszczególnieniem, że są to kazania „de tempore et de sanctis”, lecz w egzemplarzu sąsiadowickim najprawdopodobniej jej zabrakło, a spisujący bibliotekę posłużył się informacjami z żywej paginy, gdzie czytamy na samym początku: „Dominica prima adventus”.

398 Estr. XV-XVIII, t. 22, s. 59.

399 Być może chodzi o Alexandra de Villa Dei Doctrinale, które ze względu na zawartość mogłoby zostać przez inwentaryzującego mianem Vocabularius, a w egzemplarzu sąsiadowickim np. brak było karty tytułowej. Zob. IBP 5773 (Ps I), 5774 (Ps II). ISTC ia00452600. Najbardziej popularny w II połowie XV w. słownik autorstwa Johanna Reuchlina nie posiada wydania z $1499 \mathrm{r}$.

400 Estreicher nie notuje. Por. wydanie z 1717 r.: Estr. XV-XVIII, t. 32, s. 311. 
Księgozbiór karmelitów dawnej obserwancji w Sąsiadowicach

\begin{tabular}{|c|c|}
\hline 608. & Conc panegyrica - Leopoli $1766^{401}$. \\
\hline 609. & Ars cabalistica - Joan. Pistorii - Basileae. \\
\hline 610. & Biblia luterska - Brzeg szlązki $1768^{402}$. \\
\hline 611. & Com [m]entaria in psalmos - Mich Aygnanus Carm: Parisiis 1626. \\
\hline 612. & Repertorium morale - Pet. Berchorii - Venetiae 1589 - 2 tom. \\
\hline 613. & Conciones festiv: - (bez tytułu i roku). \\
\hline 614. & De Sacramento et in praec: decal. - Thomae Sanchez - Granadae $1621^{403}$ \\
\hline 615. & Plyanthea Sacra - Andr. Spener - Vind. 1738 - 5 tomów. \\
\hline 616. & Paradisus Carm. decoris - Marcus de Cassanate - Lugduni 1639. \\
\hline 617. & Defensio S. S. Trinitatis - Bern: Paxelli Cracoviae $1616^{404}$. \\
\hline 618. & Biblia sacra lit: got: (bez tytułu). \\
\hline 619. & , , editionis vulgatae ,, \\
\hline 620. & „, , idiomo gallico Lyon. 1582. \\
\hline 621. & , polska z rycinami - lit. got: ${ }^{405}$ \\
\hline 622. & „, veteris testamenti - (bez tytułu). \\
\hline 623. & Computa hujus conventus ab anno $1660-1780.3 \mathrm{księgi}^{406}$. \\
\hline 624. & Canones conc: prov. Coloniensis - Coloniae $1536^{407}$. \\
\hline
\end{tabular}

401 Estreicher nie notuje żadnego dzieła pod podobnm tytułem w 1766 r. Być może tytuł w inwentarzu został nadany sztucznie.

402 Estr. XV-XVIII, t. 13, s. 21-22.

403 Wydanie niezidentyfikowane. W $1621 \mathrm{r}$. wyszło w Lyonie trzytomowe wydanie De sancto matrimonii sacramento oraz osobne Opus morale in praecepta decalogi w dwóch woluminach.

404 Estr. XV-XVIII, t. 24, s. 170-171. Egzemplarz w BKKr, t. 1, bez sygn.

405 Ilustracje do polskich wydań Biblii wprowadzili różnowiercy, po raz pierwszy do Biblii Brzeskiej (w części ze Starym Testamencie) wydanej w 1563 r. i drukowanej gotykiem.

406 Rękopis.

407 Canones Concilii Provincialis Coloniensis, Koln 1538. Egzemplarz BKKr, sygn. XVI.683; współoprawne z Formula ad quam visitatio intra Dioecesim Coloniensem exigetur, Koln 1537, sygn. XVI.684 adl. 
Agnieszka Franczyk-Cegła

\begin{tabular}{|c|c|}
\hline 625. & Curendae et literae cursoriae Diocoes. Przemyśs $l^{408}$. \\
\hline 626. & Epitome sanctorum ad conc. 1603. \\
\hline 627. & Biblia Sw. wydanie Leopolity - bez końca ${ }^{409}$. \\
\hline 628. & Concordantia Bibliorum - Lugd. 1615. \\
\hline 629. & Bibliotheca theologica - Romae 1668. \\
\hline 630. & Historiae E[cclesia]stices Eusebii Caesar: Nürnberg $1523^{410}$. \\
\hline 631. & Expositio in E[van]g[e]lia - Bedae presbyt: Parisiis 1521. \\
\hline 632. & Cursus Theolog: moralis - Franc. a Jesu Maria, Carm: Venet 1722. \\
\hline 633. & Concion totius anni - Math. Fabri Col: 1631. \\
\hline 634. & Arbor opinionum moral: - Casiani, Carm. Ferrariae 1705. \\
\hline 635. & Rozmaite kazania, rozmaitych autorów. \\
\hline 636. & Bibliotheca Can. jur. moralis - Lucii Ferraris Romae 1759 - 2 tomy. \\
\hline 637. & Kazania niedziel: - Raym. Czaszynski - Warszawa $1745^{411}$. \\
\hline 638. & Ennarationes in 4 maj. Proph: - Dion. Carthusiani - Col: 1543. \\
\hline 639. & Concordantiae Bibliorum - Venet: 1741. \\
\hline 640. & „, majores Basileae 1543. \\
\hline 641. & Liber confraternitatis B.M.V. Sasiadovicensis ab anno $1643^{412}$. \\
\hline
\end{tabular}

408 Najprawdopodobniej rękopis.

409 Wydania Biblii Leopolity: [1] Kraków: Dziedzice Marka Szarfenerga, 1561; [2] Kraków: Mikołaj Szarfenberger, 1575. [3] toż, 1577. Zob. też rozdział Biblia Leopolity i jej przedruki (od 1561 r.) w: R. Pietkiewicz, Biblia Polonorum. Historia Biblii w języku polskim, t. 1: Od początku do 1638 roku, Poznań 2016, s. 360-382.

410 Najprawdopodobniej wydanie bazylejskie z 1523 r., egzemplarz BKKr, sygn. XVI.493 z superekslibrisem Piotra Kmity.

411 Estr. XV-XVIII, t. 14, s. 551.

412 Rękopis. Chodzi o Bractwo Matki Boskiej Szkaplerznej, uznawane za najstarsze bractwo w Sąsiadowicach, o którym dotychczas było jedynie wiadomo, że zostało powtórnie erygowane za pozwoleniem Stolicy Apostolskiej 12 VIII 1669 r. Rękopis zapisany w inwentarzu sugerowałby, że powstało ono w 1643 r. Zob. A. Franczyk-Cegła, Zarys dziejów klasztoru..., s. 90. 
Księgozbiór karmelitów dawnej obserwancji w Sąsiadowicach

\begin{tabular}{|c|c|}
\hline 642. & Commentarii de anima - Teof. Zymar. ${ }^{413}$ \\
\hline 643. & Sermones de Sanctis lit. got. (bez tytułu). \\
\hline 644. & Postillae Joannis Ferri - Col. Agrip: 1559. \\
\hline 645. & Sermones de tempore. lit. got. Argent: $1489^{414}$. \\
\hline 646. & Homiliarius Doctorum „, Basileae $1513^{415}$. \\
\hline 647. & Conciones festiv: - Stanis. Makowski - Crac. $1666^{416}$. \\
\hline 648. & Lombardica historia - lit. got Argentinae $1502^{417}$. \\
\hline 649. & Ozdoba Karmelu - Kraków 1747 - 5 tomów - 2 exempl. ${ }^{418}$ \\
\hline 650. & Cyrkularze dawniejsze swieckie i konsyst. Manuskrypt. \\
\hline 651. & Biblia s. z przypiskami - Warszawa $1821^{419}$. \\
\hline 652. & Biblia s. nakładem Jabłonowskiego Lwów $1840^{420}$. \\
\hline 653. & Skargi kazania - wydanie Bobrowicza - Lipsk 1843. \\
\hline 654. & Wielki Tydzień - Jakob Falkowski - Wilno $1829^{421}$. \\
\hline 655. & Zgodność i rowność Kościola - Skarzynski - Warszawa 1831 - 2 tomy ${ }^{422}$. \\
\hline 656. & Przewodnik młodzieży - Kaz. Gobinet - Warszawa 1829 - 2 tomy $^{423}$. \\
\hline
\end{tabular}

413 Theophili Zymarae, Marci Antonii F. in libros tres Aristotelis De anima commentarii wydane w Wenecji w 1584.

414 I. e. 1498. Chodzi o dzieło: Nicolaus de Błonie, Sermones de tempore et de sanctis sive Viridarius, Strassburg: Typographus Jordani, i.e. Georg Husner, 23 VIII 1498. IBP 3934. ISTCin00092000. Egzemplarz BKKr, sygn. XV.126, na verso karty tytułowej wpis proweniencyjny: „Hic liber est Conventus S. Annae Ord. Carmelitarum in Russia a nemine tollatur sub excommunicatione lata a Clemente VII pro Carmelitis".

415 BKKr, sygn. XVI.360.

416 Estr. XV-XVIII, t. 22, s. 59.

417 Iacobus de Voragine, Lombardica historia que a plerisq[ue] Aurea legenda sanctor[um] appellatur, Strassbourg 1502. Egzemplarz BKKr, sygn. XVI.366.

418 Estr. XV-XVIII, t. 16, s. 217.

419 Estr. XIX, t. 5, s. 174.

${ }^{420}$ Estr. XIX, t. 5, s. 175.

421 Estr. XIX, t. 1, s. 485.

422 Dzieło niezidentyfikowane.

423 Estr. XIX, t. 2, s. 47. 
Agnieszka Franczyk-Cegła

\begin{tabular}{|c|c|}
\hline 657. & Obrona Christianizmu Diyon ${ }^{424}$ Fraysinus „, $1828-4$ tomy $^{425}$. \\
\hline 658. & Material kaznodziejski - Filip Golański - Wilno $1813^{426}$. \\
\hline 659. & Nauka religii - J. Kanty Chodani - Wilno $1823^{427}$. \\
\hline 660. & Institutione[s] Theologiae dogmaticae - Greg. Ziegler - Viennae 1821 - 3 tomy. \\
\hline 661. & Heinrich Suso ’s Schriften - J. Görres - Regensburg 1837. \\
\hline 662. & O cechach prawdziwej pobozności - Warszawa $1830^{428}$. \\
\hline 663. & Bildung des Geistlichen - Conr. Tanner - Einsiedeln [1]835. \\
\hline 664. & Leben der Mönche und Einsiedler - von einem Geistlichen - Augsburg 1834. \\
\hline 665. & Kostbarkeiten für die Ewigkeit - Augs. 1834. \\
\hline 666. & Dobry wiesniak - Stan. Snarski - Wilno $1836^{429}$. \\
\hline 667. & Ksiadz pleban przez Tegoż „1835430. \\
\hline 668. & Dowody o bytności Boga - ks. Fenelon - Warszawa $1805-2$ tomy ${ }^{431}$. \\
\hline 669. & Teologia pastoralna - ks. Raczyński - Łowicz $1809^{432}$. \\
\hline 670. & Historia Jakobinizmu - ks. Baruel - Berdyczów 1812 - 4 t. ${ }^{433}$ \\
\hline 671. & Uebung der Vollkommenheit Alph. Rodriguez - Wien 1836 - 6 tomów. \\
\hline 672. & Pastoral-Anweisung - Andr. Reichenerger - Wien 1823 - 2 tomy. \\
\hline 673. & Homilie na Niedziele i Święta Andrzej Mikiewicz Lwów [1]840 ${ }^{434}$. \\
\hline
\end{tabular}

424 I.e. Dyionizy.

${ }_{425}$ Estr. XIX, t. 1, s. 515.

426 Estr. XIX, t. 2, s. 53.

427 Estr. XIX, t. 1, s. 195.

428 Estr. XIX, t. 2, s. 87.

429 Autor : Philippe-Irénée Boistel d'Exauvillez. Stanisław Snarski był tłumaczem. Estr. XIX, t. 1, s. 479 .

${ }^{430}$ Autor : Philippe-Irénée Boistel d'Exauvillez. Stanisław Snarski był thumaczem. Estr. XIX, t. 1, s. 479 .

431 Estr. XIX, t. 1, s. 491.

432 Estr. XIX, t. 4, s. 499.

433 Estr. XIX, t. 1, s. 69.

434 Estr. XIX, t. 3, s. 130. 
Księgozbiór karmelitów dawnej obserwancji w Sąsiadowicach

\begin{tabular}{|c|c|}
\hline 674. & Teolog. Zeitschrift Jos. Pletz - Wien 1834. \\
\hline 675. & Leo X, Leben und Regierung - Henri Henke Wien 18183 tomy. \\
\hline 676. & Gregor's der VII. Zeitaller - Joh. Vogt - Wien 1819. \\
\hline 677. & Florentinische Geschichtes - Nicol. Machiavelli - Wien 1827. \\
\hline 678. & Pfarr und Decanatamt - Peter Baldauf - Grätz 1836 - 6 tom. \\
\hline 679. & Kazania nied. $i$ świat: Filipeckiego $1784-4$ tom - (duplicat $)^{435}$. \\
\hline 680. & Gtos synogarlicy - Medytacye pobozne - Lwów $1759^{436}$. \\
\hline 681. & Obraz zycia roznych narodów z francuzk. Kraków 1804 - 2 tomy ${ }^{437}$. \\
\hline 682. & Diabet w swojej postaci - Jan Bohomolec Warszawa 17732 tomy ${ }^{438}$. \\
\hline 683. & Gustafs III Tod dramatisch darstellt - Leipzig 1797 - 2 tomy. \\
\hline 684. & Allgem. Weltgeschichte - J. B. Schütz - Wien $1811-8$ tom. \\
\hline 685. & Auszug der englischengeschichte - J. Lingard - Wien 1831 - 2 tomy. \\
\hline 686. & Der ewige Dom. - And. Schumacher - Wien 1834. \\
\hline 687. & Sagen der Vorzeit Leipzig $1840-2$ tomy. \\
\hline 688. & Ziemianin Galicyjski - Jul. Alex. Kamiński - Lwów 1835 - 3 tomy ${ }^{439}$. \\
\hline 689. & Geschichte Wiens - Ant. Gemau - Wien 1789. \\
\hline 690. & Schillers sämtliche Werke - Grätz 1824 w 34 tom. \\
\hline 691. & Geschichte Frankreichs - Wilh. Beckford - Leipzig 1795. \\
\hline 692. & Der Geist des h. Franz v. Sales - Wien $1830-2$ tomy. \\
\hline 693. & Geschichte der ersten Märtyrer - Teod. Ruinard - Wien [1]836. \\
\hline 694. & Geschichte v. Paraguay - Wien 1830. \\
\hline
\end{tabular}

435 Estr. XV-XVIII, t. 16, s. 218.

436 Estr. XV-XVIII nie notuje wydania z tego roku. Zob. Estr. XV-XVIII, t. 23, s. 532-533.

437 Estr XIX, t. 4 s. 49, 167.

438 Chodzi o wariant z roku 1775 bez daty na karcie tytułowej. Data „1773” pojawia się w dedykacji. Estr. XV-XVIII, t. 1, s. 230.

439 Estr. XIX, t. 2, s. 342. 
Agnieszka Franczyk-Cegła

\begin{tabular}{|c|c|}
\hline 695. & Ksiadz Pleban - tłumaczył ks. Korczyński - Lwów $1821^{440}$. \\
\hline 696. & Matpa człowiek - Manuskrypt. \\
\hline 697. & Rozstrzqsnienie chorób - przez Tyssota - Warszawa $1806^{441}$. \\
\hline 698. & Breviarium frat. Carm: I pars. Hyemalis $1762^{442}$. \\
\hline 699. & Gedanken über die Restauration der Kirche in Deutschland - $1859^{443}$ \\
\hline 700. & Moser's Kanzelreden - D. Kaß - $1831-2$ tomy ${ }^{444}$. \\
\hline 701. & Dyariusz wiedeńskiey okazyi - Mik. Dyakowski $1863^{445}$. \\
\hline 702. & Manuale sacerdotum - Jos. Schneider $1863^{446}$. \\
\hline 703. & Panis quotidianus juventutis sacrae - Gaud Pikulski $1759^{447}$. \\
\hline 704. & Kazania - ks. Holowinskiego $1857^{448}$. \\
\hline 705. & Breviarium Carm. pars hiemalis $1730^{449}$. \\
\hline 706. & Kubczorski i Skarga-Ant. Sozański $1839^{450}$. \\
\hline 707. & Predigten für Feste Mariens - Pasqual Skerbinz $1820^{451}$. \\
\hline 708. & Obrona prawdy $1846^{452}$. \\
\hline 709. & Nauki prawd wiary - ks. de Toul $1842^{453}$. \\
\hline 710. & Meditationes OICIOCCLX ${ }^{454}$. \\
\hline
\end{tabular}

${ }^{440}$ Autorem był Jean Michel Sailer. Estr. XIX, t. 4, s. 172.

${ }_{441}$ Estr. XIX, t. 4, s. 585.

442 Wydanie niezidentyfikowane.

443 Wydane w Regensburgu.

444 Wydane we Frankfurcie nad Menem.

445 Wydane w Krakowie. Estr. XIX, t. 1, s. 429.

446 Wydane w Kolonii.

447 Wydane we Lwowie. Estr. XV-XVIII, t. 24, s. 275.

448 Wydane w Krakowie. Estr. XIX, t. 2, s. 145.

449 Wydane w Antwerpii pod tytułem Breviarium fratrum B. Dei Genitricicis virginis Mariae de monte Carmelo. Pars hiemalis.

450 Wydane w Wiedniu. Estr. XIX, t. 4, s. 319.

451 Wydane w Wiedniu.

452 Czasopismo wydawane w Poznaniu. Estr. XIX, t. 4, s. 604.

453 Wydane we Lwowie. Estr. XIX, t. 4, s. 519.

454 Być może np. Dissertatio philosophica meditationes quasdam de gustu in litteris praecipue 
Księgozbiór karmelitów dawnej obserwancji w Sąsiadowicach

\begin{tabular}{|c|c|}
\hline 711. & Lekcye i Ewangelie - Ant. Tyc $1855^{455}$. \\
\hline 712. & O mieście Bożem ks. Mat. Gładyszewicz $1835^{456}$ \\
\hline 713. & Biblioteka kieszonkowa klasyków polskich Bobrowicz $1859^{457}$. \\
\hline 714. & Przewodnik dla spowiedników - Urban Rokicki -2 tomy ${ }^{458}$. \\
\hline 715. & Swięte niewiasty przez Hofmanowę $-1843-3$ tomy $y^{459}$. \\
\hline 716. & Biblia nowego testamentu ks. Wójko $[!]-1838^{460}$. \\
\hline 717. & Philothea. $1839^{461}$. \\
\hline 718. & Teologia pastoralna. Tom I $1844^{462}$. \\
\hline 719. & Moralis christiana - Polaschek $-1803^{463}$. \\
\hline 720. & Medycyna wyleczajaca - Roy $1830^{464}$. \\
\hline 721. & Historya kościola ruskiego Lawrowski $1857^{465}$. \\
\hline 722. & Dykcyonarz biblijny pr. Prospera $1845-4$ tomy $y^{466}$. \\
\hline 723. & Wspomnienie o s. Kunegundzie - Antoniewicz der Welt - Mettenleiter $1858^{468}$. \\
\hline
\end{tabular}

elegantioribus exhibens, gdzie datę również zapisano w ten sposób.

455 Wydane w Lesznie. Estr. XIX, t. 4, s. 547.

456 Wydane w Krakowie. Estr. XIX, t. 2, s. 43.

457 Wydane w Lipsku w 37 tomach. Estr. XIX, t. 1, s. 99.

${ }_{458}$ Autor: Jean Joseph Gaume. Urban Rokicki był thumaczem. Wydane w Wilnie. Estr. XIX, t. 2 , s. 16 .

459 Wydane w Lipsku. Estr. XIX, t. 2, s. 138.

460 Wydane w Lipsku. Estr. XIX, t. 5, s. 175.

461 Wydane w Würzburgu.

462 I.e. Teologia pasterska z różnych autorów Juliana Zagórskiego. Wydane we Lwowie. Estr. XIX, t. 5, s. 225.

463 Wydane w Ołomuńcu. Por. wydanie wileńskie: Estr. XIX, t. 3, s. 454.

464 Wydane w Warszawie. Estr. XIX, t. 2, s. 579.

${ }^{465}$ Autor: Franceso Gusti. Jan Ławrowski był thumaczem. Wydane w Krakowie. Estr. XIX, t. 2, s. 97.

466 Autor: Prosper Aquila. Wydane w Krakowie. Estr. XIX, t. 1, s. 37.

467 Gniezno-Leszno, 1849.

468 Wydane w Regensburgu. 
Agnieszka Franczyk-Cegła

\begin{tabular}{|c|c|}
\hline 725. & Nauki z historyi ewangeliynej przez Dziubackiego $1858^{469}$. \\
\hline 726. & Praktischer Lehrgang der italienischen Sprache - Filippi $1846^{470}$. \\
\hline 727. & Passionspredigten v. Buchberger. $1845^{471}$. \\
\hline 728. & Betrachtungen von einem Priester der Diözese Rottenburg $1860^{472}$. \\
\hline 729. & Virginitas Donin $1859^{473}$. \\
\hline 730. & Leben der ersten Mütter und Schwestern Lud. Clarus ${ }^{474}$. \\
\hline 731. & Neue Methode für die engl: Sprachen H: D: Ollendorf ${ }^{475}$. \\
\hline 732. & Französische Sprachlehre - Legat ${ }^{476} 1834$. \\
\hline 733. & Biliothek für innerl. Seelen II Aufl. V. Merlo Hortius ${ }^{477}$. \\
\hline 734. & Bild un [d]Wort - Stelzig $1859^{478}$. \\
\hline 735. & Additamenta $1839^{479}$. \\
\hline 736. & Buch der heil480 Liebe - v Donin $1860^{481}$. \\
\hline 737. & Praedigten v. Dix $1842^{482}$. \\
\hline
\end{tabular}

469 Autor: Francesco Finetti. Jan Dziubacki był thumaczem. Wydane w Warszawie. Estr. XIX, t. 1 , s. 498 .

470 Wydane w Wiedniu.

471 Wydane w Regensburgu.

472 I.e. Betrachtungen über das Leben der allerseligsten Jungfrau ... Ins Deutsche übersetzt von einem Priester der Diözese Rottenburg autorstwa Paza de Alvareza.

473 Wydane w Wiedniu.

474 Chodzi o tom 4 i 5 Leben des heiligen Franz von Sales, Stifters des Ordens von der Heimsuchung Mariens, der heiligen Johanna Franzisca von Chantal und ihrer ersten Ordensschwestern autorstwa Ludwiga Clarusa, wydane pod własnym tytułem Leben des ersten Mutter und Schwestern des Ordens von der Heimsuchung Mariens (Schaffhausen 1861).

475 Wydane we Frankfurcie nad Menem w 1856 r. bądź w Altenburg w 1867 r.

476 Druk autorstwa Johanna Baptista Machata wydał Georg Legat w Wiedniu.

477 I.e. Sacrosancta missa Jakoba Merlo-Horstiusa wydana w Schaffhausen w 1860 r. jako tom 2 serii Bibliothek für innerliche Seelen.

478 Regensburg: Georg Joseph Manz.

479 Najprawdopodobniej Additamenta ad literaturae Romanae historiam Juliusa Helda wydane w tymże roku w Świdnicy.

480 I.e. heiligen.

481 Wydane w Wiedniu.

482 I.e. Das katholische Festjahr. Oder Predigten auf die vornehmsten katholischen Festtage autorstwa Johanna Martina Düxa wydane w Regensburgu. 
Księgozbiór karmelitów dawnej obserwancji w Sąsiadowicach

\begin{tabular}{|c|c|}
\hline 738. & Gebete für alle Tage der Woche Hugues ${ }^{483}$. \\
\hline 739. & Die Todtenhand - v. Prince ${ }^{484}$. \\
\hline 740. & Handuch der $k$ : $k$ : Gesetze und Verordnungen $\mathrm{v}$. Dt Reider ${ }^{485} 1848$ - 3 tomy ${ }^{486}$ \\
\hline 741. & Gtos Pana krzyzuiacego - Rebczynski $1768^{487}$. \\
\hline 742. & Droga do szczęścia $1840^{488}$. \\
\hline 743. & Poradnik domowy - Jasinski - część I $1865^{489}$. \\
\hline 744. & Wspomnienia podchorążego - Komorowski $1863^{490}$. \\
\hline 745. & O życiu i pismach Thad. Czackiego pr. Osinskiego $1851^{491}$. \\
\hline 746. & Handbuch der christl. Moral - Seiler ${ }^{492} 1818^{493}$. \\
\hline 747. & Listy $w$ duchu Bożym - Antoniewicz $1858^{494}$. \\
\hline 748. & Miesiąc Maj $1839^{495}$. \\
\hline 749. & Pamiątki ${ }^{496}$ Franciszka Karpinskiego p. Moraczewskiego [1]844 ${ }^{497}$. \\
\hline 750. & Ojciec Karol Antoniewicz 1852. \\
\hline
\end{tabular}

483 Der Priester im Gebete und in der Betrachtung. Gebete für alle Tage der Woche autorstwo Alfonsa Marii de' Liguori wydane przez Markusa Huguesa w Regensburgu w 1843 r.

484 Chodzi o niemieckie thumaczenie kontynuację Hrabiego Monte Christo Aleksandra Dumasa pt. La Main du defunt (niem. Die Todtenhand) autorstwa bliżej nieznanego F. Le Prince, wydaną po raz pierwszy po francusku w 1853 r., a po niemiecku wydawaną m.in. w 1861 i 1866 r.

485 I.e. Von Dr. Franz Reider.

486 Wydane w Wiedniu.

${ }^{487} \mathrm{Tj}$. Glos Pana kruszacego... Rubczyńskiego. Wydane w Berdyczowie. Estr. XV-XVIII, t. 26 , s. $436-437$.

488 Autor: Józef Droz. Wydane w Krakowie. Estr. XIX, t. 1, s. 415.

489 Prawdopodobnie pomyłka w dacie. O leczeniu woda i innemi środkami naturalnemi. Poradnik domowy dla zwolenników kuracyi woda Władysława Jasińskiego wyszedł we Lwowie w 1864 r. Estr. XIX, t. 2, s. 210.

490 Wydane we Lwowie. Estr. XIX, t. 2, s. 414-415.

491 Wydane w Krakowie. Estr. XIX, t. 3, s. 320.

492 I.e. Sailer.

493 Wydane w Wiedniu.

494 Prawdopodobnie pomyłka w dacie. Wydanie to wyszło we Lwowie w 1850 i 1857. Estr. XIX, t. 1, s. 33.

495 Autor: Jan Piotr Becks. Wydane we Lwowie. Estr. XIX, t. 1, s. 78.

496 I.e. Pamiętniki.

497 Wydane w Poznaniu. Estr. XIX, t. 1, s. 56. 
Agnieszka Franczyk-Cegła

\begin{tabular}{|c|c|}
\hline 751. & Liber regulae pastoralis. \\
\hline 752. & Poezye ks. Antoniewicza $1861^{498}$. \\
\hline 753. & O wolności p. Starkla $1864^{499}$. \\
\hline 754. & O obrządkach kościoła kat: p. ks. Terklau ${ }^{500}$. \\
\hline 755. & Wyktad listów sw. Pawła prz. ks. Serwatowskiego $1850^{501}$. \\
\hline 756. & Pamiatniki o ks. Radziwille Naswiezewski ${ }^{502} 1864^{503}$. \\
\hline 757. & Nowa polska - p. Dluzniewskiego $1863^{504}$. \\
\hline 758. & Nowe podstawy praw narodowych $\mathrm{p}$. Widmana [1]864 ${ }^{505}$. \\
\hline 759. & Narodowość a rewolucya $\mathrm{p}$. Widmana $1864^{506}$. \\
\hline 760. & Kościół na Piasku Rogalski $1863^{507}$. \\
\hline 761. & Instructio Novitiorum $1861^{508}$. \\
\hline 762. & Entwürfe zu Predigten A v. Guilois II Th. $1857^{509}$. \\
\hline 763. & Fastenpredigten $\mathrm{v}$. Hungari $1843^{510}$. \\
\hline 764. & $\begin{array}{l}\text { Dwa lata dziejów naszych } 1846 \text { i } 1848 \text { przez Karola Szajnoch Tom I Polska roku } \\
\qquad 1846-1865^{511} \text {. }\end{array}$ \\
\hline 765. & Dzieje powszechne - Stan. Zarańskiego Tom II $1855^{512}$. \\
\hline
\end{tabular}

\footnotetext{
498 Wydane w Krakowie. Estr. XIX, t. 1, s. 34.

499 Autor: John Stuart Mill. Juliusz Starkel był thumaczem. Wydane we Lwowie. Estr. XIX, t. 3, s. 135.

500 Wydane w Lesznie w 1858 r. Estr. XIX, t. 4, s. 500.

501 Wydane w Krakowie. Estr. XIX, t. 4, s. 228.

502 Błędne odczytanie tytułu, który brzmi: Pamiętnik o księciu Karolu Radziwille pisany podtug archiwum nieświezkiego.

503 Wydane we Lwowie. Estr. XIX, t. 4, s. 17.

504 Wydane w Przemyślu. Estr. XIX, t. 1, s. 19.

505 Wydane we Lwowie. Estr. XIX, t. 5, s. 56.

506 Jest to rozdział pierwszy z Nowych podstaw praw narodowych. Zob. pozycję wyżej.

507 Wydane w Krakowie. Estr. XIX, t. 4, s. 79.

508 Autor: Joannes a Jesu Maria. Wydane w Graz.

509 Wydane w Regensburgu.

510 Wydane w Moguncji.

511 I.e. Dwa lata dziejów naszych 1646-1648. Wydane we Lwowie. Estr. XIX, t. 4, s. 429.

512 Wydane we Lwowie. Estr. XIX, t. 5, s. 248.
} 
Księgozbiór karmelitów dawnej obserwancji w Sąsiadowicach

\begin{tabular}{|c|c|}
\hline 766. & Obraz N. P. M. p. ks. Leona Ulanowskiego $1853^{513}$. \\
\hline 767. & Listy w przedmiotach naukowych ks. Hugona Kołłątaja 1844 - 2 tomy $^{514}$. \\
\hline 768. & Kazania p. Zygmunta Goliana $1858^{515}$. \\
\hline 769. & Die h. Psalmen nach der Vulgata $1859^{516}$. \\
\hline 770. & Compendium per Fr. K: O. O. S. B. M. $1817^{517}$. \\
\hline 771. & Dzieje powszechne soboru Trydyn. [!] p. Felix Słotwińskiego $1857^{518}$. \\
\hline 772. & $\begin{array}{c}\text { Przemówienie w czasie załobnego Nabożeństwa za duszę sw. pamięci Stanist. Roga- } \\
\text { skiego - p. ks. Henryka Księgarskiego } 1859^{519} \text {. }\end{array}$ \\
\hline 773. & Uwagi nad sekta Rongego i Czerskiego $1850^{520}$. \\
\hline 774. & Kath. Religionsuenterricht $1834^{521}$. \\
\hline 775. & Ecce Homo v. Anton Niederhuber ${ }^{522}$. \\
\hline 776. & Nauka chrześcianska - p. Karczowskiego Tom IX $1829^{523}$. \\
\hline 777. & Historya sw. młodości J. Ch. przez Kosickiego Tom VIII $1829^{524}$. \\
\hline 778. & Przewodnik młodzieży chrzescianskiej przez Kosickiego Tom VIII $1829^{525}$. \\
\hline
\end{tabular}

513 Wydane we Lwowie. Estr. XIX, t. 4, s. 598

514 Tom 4 Korrespondencyi listownej z Tadeuszem Czackim. Wydane w Krakowie przez Fernynanda Kojsiewicza. Estr. XIX, t. 2, s. 409.

515 Wydane w Krakowie. Estr. XIX, t. 2, s. 55.

516 Wydane w Linz.

517 I.e. Compendium Hermeneuticae Generalis Librorum Veteris novi foederis usui Studiosorum Sacrae Scripturaeae accommodatum Floriana Kudrewicza. Wydane w Krakowie. Estr. XIX, t. 2 , s. 520 .

518 Wydane w Krakowie. Estr. XIX, t. 4, s. 278.

519 Wydane w Krakowie. Estr. XIX, t. 2, s. 514.

520 Autor: Feliks Słotwiński. Wydane w Krakowie. Estr. XIX, t. 4, s. 279.

521 Wydane w Wiedniu.

522 Wydane w Linz w 1858 r.

${ }_{523}$ Autor: C.F.L'Homond. Wincenty Roch Karczewski był thumaczem. Wydane w Warszawie. Estr. XIX, t. 2, s. 594.

524 I.e. Historya świętej młodości Jezusa Chrystusa autorstwa Jeana Urbaina Grisota. Modest Watt Kosicki był tłumaczem. Wydane w Warszawie w $1826 \mathrm{r}$. Tu zapewne błąd per analogiam do pozycji niżej. Estr. XIX, t. 2, s. 83.

${ }_{525}$ Autor: Karol Gobinet. Modest Watt Kosicki był tłumaczem. Wydane w Warszawie. Estr. XIX, t. 2, s. 477. 
Agnieszka Franczyk-Cegła

\begin{tabular}{|c|c|}
\hline 779. & Wieńce pieśni zebrackich - p. Michała Suchorowskiego $1860^{526}$. \\
\hline 780. & O obrzadkach gr. unickich $1862^{527}$. \\
\hline 781. & Kazania pr. Gwilelma Kalińskiego $1808^{528}$. \\
\hline 782. & $\begin{array}{l}\text { Przepowiednie najstawniejszych proroków i wieszczów o przyszlych losach Europy } \\
\text { p. A. Tessarczyka } 1850^{529} \text {. }\end{array}$ \\
\hline \multicolumn{2}{|c|}{$\begin{array}{c}\text { Dzieła pod liczbami porzadkowymi: } l .34,101,123,129,132,137,148,162,164,166,168,177, \\
\text { 191, 209, 211, 222, 249, 262, 324, 369, 371, 380, 387, 393, 412, 421, 424, 428, 429, 430, 431, } \\
\text { 452, 479, 480, 483, 493, 593, 625, 626 w tym inwentarzu wymienione, które wedtug katalogu } \\
\text { bibliotecznego w roku 1856 oporzadzonego, znajdowaty się jeszcze w bibliotece klasztornej, } \\
\text { obecnie brakuja. Właściwa przyczyna członkowie klasztoru nie umieja podać; przypisuja atoli } \\
\text { takowa poczéści zniszczeniu przez mole, poczéściej zaś tej okoliczności, że niektóre dzieła poza } \\
\text { klasztor wypożyczone, nie zostaty napowrót zwrócone, gdyż żadna w tej mierze nie prowadzita } \\
\text { się ewidencya. }\end{array}$} \\
\hline
\end{tabular}

\begin{tabular}{|c|c|}
\hline \multicolumn{1}{|c|}{ X. Dokumenta } \\
Erekcya: \\
\hline 1. & Consecratia ecclesia S. Annae in Sasiadowice d. 15: Septbr. 1591 \\
\hline 2. & $\begin{array}{r}\text { Facultas Ill. Loci Ordinarii exstruendi claustrum caenubiale ad ecc. S. Annae, Car- } \\
\text { melitis concessa 1603. }\end{array}$ \\
\hline 3. & $\begin{array}{c}\text { Testimonium St. Herburti super eo quod Erasmus Herburtus a inadvertendi praecipi- } \\
\text { tantia lucraverit jus plebanium pro duobus cmetonibus 1600. }\end{array}$ \\
\hline 4. & $\begin{array}{c}\text { Testomonium juridice facta, tam de cmetonibus, pratis, decimis, nec non aliis proven- } \\
\text { tibus ecc. parochialis Sasiadovicensis ad St. Nicolaum 1600. }\end{array}$ \\
\hline 5. & $\begin{array}{c}\text { Breve Apost: pro erectione conventus S. Annae p. p. Carmel. quibus ecclesia Fulsty- } \\
\text { nensis, tum cura animorum, tum cum omnibus fructibus ad eorum sustentationem } \\
\text { conceditur 1605. }\end{array}$ \\
\hline 6. & $\begin{array}{c}\text { Breve Apost: concedens p. p. Carmel. ad St. Annam eccl: paroch: una cum fructuum } \\
\text { pro eorum sustenatione actis Consist: Poznaniensis ingrosatu[m] 1605. }\end{array}$ \\
\hline
\end{tabular}

526 Wydane we Lwowie. Estr. XIX, t. 4, s. 406.

527 Autor: Jan Boliński. Wydane we Lwowie. Estr. XIX nie notuje.

528 Wydane w Krakowie. Estr. XIX, t. 2, s. 337.

529 Wydane w Cieszynie. Estr. XIX, t. 4, s. 501. 
Księgozbiór karmelitów dawnej obserwancji w Sąsiadowicach

\begin{tabular}{|c|c|}
\hline 7. & $\begin{array}{c}\text { Errectio ecclesiae et conventus per Joannem Felixem Herburt et Erasmem Adalber- } \\
\text { tum Herburt ; d. } 11 \text { Martii } 1608 .\end{array}$ \\
\hline 8. & $\begin{array}{c}\text { Joannes Felix Herburt, una cum Erasmo Adalberto Herburt et habita licentia su- } \\
\text { m[m]i ssignatio et loci Ordin: ecclesiam paroch. S. Nicolai in Sasiadowice, conventui } \\
\text { p. p. Carmelit. ad St. Annam perpetuo incorporavit, cum omnibus fructibus, d. } 2 \text { Oct. } \\
1609 .\end{array}$ \\
\hline 9. & $\begin{array}{l}\text { Erasm : Adalb. Herburt una cum concessu sui tutoris eccl. S. Anna }[m] \text { muro extruc- } \\
\text { tam, donat p. p. Carmel. quibus etiam adjungit eccl : paroch : St. Nicolai in Sasiado- } \\
\text { wice cum omnibus ejus attenentiis } ; \text { d. } 28 . \text { Sept. } 1610 .\end{array}$ \\
\hline 10. & $\begin{array}{c}\text { Incorporatio eccl: paroch: Sasiadow: per fundatores et concessarios a loci Ordinario } \\
\text { deputatos d. } 9 . \text { Oct. } 1612 .\end{array}$ \\
\hline 11. & $\begin{array}{l}\text { Diploma donationis eccl: S. Annae per Erasmum Herburt, filium Fundatoris cum as- } \\
\text { signatione censui perpetui et salis Dobromiliensibus per } 100 \text { fr. quotannis solvendae } \\
\qquad \text { d. } 13 \text { Januarii } 1613 .\end{array}$ \\
\hline 12. & $\begin{array}{c}\text { Erazm Albert Herburt fundator quinque cmetones in Sasiadowice, libela incisione in } \\
\text { silvis, molitu[di]nem frumentorum, duos cmetones plebanales, conventui S. Annae } \\
\text { donat, conscribit et resignat. }\end{array}$ \\
\hline 13. & $\begin{array}{c}\text { Breve Apost: approbans corporationem parochiae S: Nicolai cum Conventu Carmeli- } \\
\text { torum ad S. Annam d. } 12 . \text { Novb: } 1683 .\end{array}$ \\
\hline 14. & Castrum Przemyśl: approbans idem. - d. 21. Apr. 1687. \\
\hline 15. & $\begin{array}{l}\text { Succesores fundatorum: Eustachius et Isabella Tyszkiewicze approbant donationem } \\
\text { pro Conventui Carm. S. Annae factam d. } 20 \text { Oct. } 1685 .\end{array}$ \\
\hline $16-34$ & {$[\text { Donacje }]^{530}$} \\
\hline & Inne dokumenta: \\
\hline 35. & $\begin{array}{l}\text { Propugnanda S. Montis Placidi, seu Monimenta legalia ecclesiae et conventui } S . \\
\text { Annae, ab anno 1591-1745. constat ex pag : 1-435. }\end{array}$ \\
\hline
\end{tabular}

${ }_{530}$ Pod nr 16-34 inwentarza bibliotecznego zapisano donacje na rzecz kościoła i klasztoru, zob. ich odpis w: A. Franczyk-Cegła, Zarys dziejów klasztoru..., dz. cyt., s. 110. 


\begin{tabular}{|c|c|}
\hline 36. & Collecta sive Registrum omnium transactionum, ab an[n]o 1591-1764, pagina 1-274. \\
\hline 37. & $\begin{array}{c}\text { Orzeczenie c: } k: \text { Namiestnictwa jako dyrekcyi funduszów indemnizacyjnych z dnia } 20 \\
\text { paździer. } 1870 \text { l. } 6817 / \text { D.F. odsytajace wtościan ze Sasiadowic z pretensya do klaszto- } \\
\text { ru o dwie taki, do drogi prawa. }\end{array}$ \\
\hline
\end{tabular}

\section{Bibliografia}

Źródła rękopiśmienne:

Archiwum OO. Karmelitów na Piasku w Krakowie

Archiwum Archidiecezjalne w Przemyślu

Centralne Państwowe Archiwum Historycznym Ukrainy we Lwowie

Lwowska Narodowa Naukowa Biblioteka Ukrainy im. W. Stefanyka

Zakład Narodowy im. Ossolińskich

Opracowania:

Buca J., [Repatriacje - ewakuacja. Tekst na podst. dokumentów zespołu nr 527/0 AAN (Rejonowego Pełnomocnika Rządu RP do Spraw Ewakuacji Ludności Polskiej z Ukraińskiej SRR w Samborze,1944-1946)], [online], http://ubocze66.republika.pl/ repatriacje/ewakuacja.html, (dostęp 30.01.2016.

Ciborowska-Rymarowicz I., Polonika $w$ księgozbiorze klasztornym karmelitów bosych w Berdyczowie (na podstawie katalogu z 1781 r.). Zarys problemu, „Z Badań nad Książką i Księgozbiorami Historycznymi”, tom specjalny, 2017, s. 219-27.

Dzieje teologii katolickiej w Polsce. T. 3, Wiek XIX i XX. Cz. 1, red. M. Rechowicz, Lublin 1976.

Franczyk-Cegła A., Fragmenty księgozbioru klasztoru karmelitów w Sąsiadowicach w zbiorach Zakładu Narodowego im. Ossolińskich, „Hereditas Monasteriorum” 2015, nr 6, s. 251-290.

Franczyk-Cegła A., Zarys dziejów klasztoru oo. karmelitów w Sąiadowicach, „Nasza Przeszłość" 2015, nr 125, s. 75-126.

Franczyk-Cegła A., Knyhozbirnia oo.karmelitiw z Susidowycziw u zibranniach Lwiwśkoji Nacionalnoji Naukowoji Biblioteky Ukrajiny im.W. Stefanyka i Nacionalnoho Zakładu im. Ossolinśkych u Wrocławi, „Zapysky Lwiwśkoji Nacionalnoj i naukowoji biblioteky Ukrajiny imeni W. Stefanyka" 2017, t. 9 (25), s. 24-57.

Kwolek J., Archiwa diecezji przemyskiej ob. łac., Przemyśl 1927.

Paszkiewicz U., Inwentarze i katalogi bibliotek z ziem wschodnich Rzeczypospolitej do 1939 r. Suplement 1, Warszawa 2000.

Radziszewski F., Wiadomość historyczno-statystyczna: o znakomitszych bibliotekach $i$ archiwach, publicznych i prywatnych tak niegdyś ... w Królestwie Polskiem, Galicyi, W. Ks. Poznańskiem i Zachodnich guberniach Państwa Rossyjskiego, Kraków 1875. 
Schematismus des Königreiches Galizien und Lodomerien Für das Jahr 1827, Lemberg [1826].

Schematismus universi venerabilis cleri saecularis et regularis dioecesis rit. lat. Premisliensis pro Anno Domini 1866, Jasło 1865.

Smereka J., Ojcowizna [mps], Wrocław 1996.

Wąsowicz M., Ze wspomnień archiwisty (1929-1953), „Miscellanea Historico-Archivistica" 1985, t. 26, s. 91-97.

Żuk P.S., Sąsiadowice 1939-1945 [mps], Wrocław 1990. 